Article

\title{
Advanced Ultra-Supercritical Coal-Fired Power Plant with Post-Combustion Carbon Capture: Analysis of Electricity Penalty and $\mathrm{CO}_{2}$ Emission Reduction
}

\author{
Branimir Tramošljika, Paolo Blecich *D, Igor Bonefačić (D) and Vladimir Glažar
}

check for

updates

Citation: Tramošljika, B.; Blecich, P.; Bonefačić, I.; Glažar, V. Advanced

Ultra-Supercritical Coal-Fired Power Plant with Post-Combustion Carbon Capture: Analysis of Electricity Penalty and $\mathrm{CO}_{2}$ Emission Reduction. Sustainability 2021, 13, 801. https:// doi.org/10.3390/su13020801

Received: 25 November 2020 Accepted: 13 January 2021 Published: 15 January 2021

Publisher's Note: MDPI stays neutral with regard to jurisdictional clai$\mathrm{ms}$ in published maps and institutional affiliations.

Copyright: $(\odot 2021$ by the authors. Licensee MDPI, Basel, Switzerland. This article is an open access article distributed under the terms and conditions of the Creative Commons Attribution (CC BY) license (https:// creativecommons.org/licenses/by/ $4.0 /)$.
Faculty of Engineering, University of Rijeka, 51000 Rijeka, Croatia; branimir.tramosljika@hotmail.com (B.T.); igor.bonefacic@riteh.hr (I.B.); vladimir.glazar@riteh.hr (V.G.)

* Correspondence: paolo.blecich@riteh.hr

\begin{abstract}
This article presents the performance analysis of a $700 \mathrm{MW}$ future planned advanced ultra-supercritical (A-USC) coal-fired power plant fitted with post-combustion carbon capture and storage (CCS) technology. The reference A-USC unit without CCS achieves a net efficiency of $47.6 \%$ with $\mathrm{CO}_{2}$ emissions of $700 \mathrm{kgCO}_{2} / \mathrm{MWh}$. Relatively to subcritical units, the net efficiency of the A-USC is $8 \%$-pts higher while $\mathrm{CO}_{2}$ emissions are $16.5 \%$ lower. For a $\mathrm{CO}_{2}$ removal rate of $90 \%$, the net efficiency of the CCS integrated A-USC unit is $36.8 \%$. The resulting net efficiency loss is $10.8 \%$-pts and the electricity output penalty is $362.3 \mathrm{kWh}_{\mathrm{el}} / \mathrm{t}_{\mathrm{CO} 2}$ for present state CCS technology. The study continues with the assessment of interface quantities between the capture unit and the steam cycle affecting the performance of the A-USC. Improved $\mathrm{CO}_{2}$ absorbents could alleviate the net efficiency loss by $2-3 \%$-pts, and enhanced $\mathrm{CO}_{2}$ compression strategies and advanced heat integration could further reduce the efficiency loss by $0.5-1.2 \%$-pts and $0.4-0.6 \%$-pts, respectively. The total efficiency gain from CCS technology upgrades is estimated at 3.6\%-pts, thus bringing down the net efficiency loss to $7.2 \%$-pts and the electricity output penalty to $241.7 \mathrm{kWh}$ el $/ \mathrm{t}_{\mathrm{CO} 2}$.
\end{abstract}

Keywords: advanced ultra-supercritical; coal-fired power plant; post-combustion carbon capture; net efficiency loss; electricity output penalty; carbon emissions

\section{Introduction}

Nowadays, fossil fuels are still the backbone of power generation. In 2019, fossil fuels generated $62.7 \%$ of the total global electricity [1]. By energy source, coal contributes with $36.4 \%$ in the total electricity generation [1]. Due to pressing environmental and climate concerns, decarbonization of the electric power industry has become imperative. The IEA scenarios in the 2020 World Energy Outlook predicts the reduction of $\mathrm{CO}_{2}$ emissions from the power industry by as much as $60 \%$ between 2020 and 2030 [2]. Three-fourths of this reduction will be achieved from the rapid decline of conventional coal-fired generation. However, the share of advanced supercritical coal power plants is expected to rise in order to meet the ongoing growth in global electricity demand [3]. Supercritical steam cycles paired to carbon capture and storage (CCS) technologies are going to be integrated into future clean coal power plants [4]. By 2030, most of the advanced coal power plants will be upgraded with carbon capture, utilization, and storage (CCUS) technologies.

Subcritical power plants (SUBC) achieve thermal efficiency in the range between $34 \%$ and $40 \%$ (based on coal LHV) with the global average efficiency around 36\%, whereas modern supercritical power plants (SC) reach efficiencies between $42 \%$ and $45 \%$ [5]. Ultra-supercritical power plants (USC) employ advanced metal alloys to withstand extreme steam conditions and achieve even higher efficiencies. A record-high net efficiency of $47.5 \%$ was achieved by the RDK Block 8 unit in Germany [6]. This is due to the elevated steam conditions: Superheat and reheat steam temperatures of $600 / 620{ }^{\circ} \mathrm{C}$ and steam pressures of up to 275 bar. Advanced ultra-supercritical power plants (A-USC) are expected to enter operation in the next decade 
and will approach 50\% net electricity generation efficiency [7] with the use of advanced metal alloys capable of withstanding steam temperatures and pressures over $700{ }^{\circ} \mathrm{C}$ and 350 bar $[8,9]$. These advanced alloys (superalloys) are being developed by adding chromium (Cr), nickel $(\mathrm{Ni})$, cobalt (Co), vanadium (V), wolfram (W), and molybdenum (Mo) to ferritic steels to obtain higher temperature- and corrosion-resistance $[5,8]$.

Increased thermal efficiency leads to reduced emissions of greenhouse gases and pollutants. To put it into perspective, replacing an old conventional subcritical power plant with a new supercritical corresponds to a $10 \%$ efficiency gain and a $\mathrm{CO}_{2}$ emission reduction of more than $20 \%$. For example, a conventional coal-fired power plant generates electricity at $36 \%$ thermal efficiency while having specific emissions of around $1000 \mathrm{kgCO} / \mathrm{MWh}_{\mathrm{el}}$. An USC unit with $46 \%$ thermal efficiency generates $28 \%(0.46 / 0.36=1.28)$ more electricity per unit of fuel heat input than the subcritical unit, whereas the emissions are $781 \mathrm{kgCO} / \mathrm{MWh}_{\mathrm{el}}$ $(1000 / 1.28=781)$, a $21.9 \%$ reduction. A-USC coal power plants could achieve even lower $\mathrm{CO}_{2}$ emissions, around $700 \mathrm{~kg} / \mathrm{MWh}$ [10]. Further $\mathrm{CO}_{2}$ emission reductions, down to $100 \mathrm{~kg} / \mathrm{MWh}$, would be possible only with the implementation of post-combustion carbon capture and storage (CCS) for the treatment of flue gases released during fossil fuel combustion.

The Global Status of CCS 2020 [11] reports 26 commercial CCS facilities currently in operation with a total capture and storage capacity of 40.7 million tonnes of $\mathrm{CO}_{2}$ per year (Mtpa). CCS units are being used in the following industries: Natural gas processing (30.5 Mtpa), power generation (2.4 Mtpa), hydrogen production (2.2 Mtpa), fertilizer production (1.8 Mtpa), methanol and ethanol production (1.6 Mtpa), oil refining (1.4 Mtpa), iron and steel production (0.8 Mtpa). At present, two capture demonstration projects are up and running in the power generation sector: The Boundary Dam power plant and the Petra Nova power plant [12]. Both are using amine-based post-combustion capture, applied on one coal-fired unit each, and the captured carbon is transported via pipelines to enhanced oil recovery fields. Enhanced oil recovery (30.7 Mtpa) and storage in dedicated geological formations (10 Mtpa) are the two types of carbon storages used in these industries. By 2050, the CCS sector is envisioned to grow to a total global installed capacity of $5600 \mathrm{Mtpa}$ of $\mathrm{CO}_{2}$ [11].

The estimated costs of CCS projects for fossil fuel power plants span over wide ranges of values, as reported in the relevant literature [13,14]. The costs of CCS depend on the fuel type, the costs of labor, materials, operation and maintenance, the carbon capture technology, the costs of transport and storage, and the type of project (greenfield or retrofit). The levelized cost of electricity (LCOE) is between 61 and $87 \mathrm{US} \$ / \mathrm{MWh}$ in power plants without CCS and between 94 and 163 US\$/MWh for power plants with CCS $[13,14]$. The LCOE could be reduced to between 61 and 139 US\$/MWh when the captured $\mathrm{CO}_{2}$ is sold to enhanced oil recovery projects instead of simply storing it in geological formations. The cost of captured $\mathrm{CO}_{2}$ is between 33 and $58 \mathrm{US} \$ / \mathrm{t}_{\mathrm{CO}}$, while the cost of avoided $\mathrm{CO}_{2}$ (including compression, transport, and storage) is between 44 and $86 \mathrm{US} \$ / \mathrm{t}_{\mathrm{CO} 2}[13,14]$. Post-combustion CCS for combined cycle natural gas turbines (CCGT) or SCPC power plants with oxy-fuel combustion are predicted to operate with similar costs. Slightly higher costs were estimated for coal-based integrated gasification combined cycles (IGCC) with pre-combustion CCS [14]. The specific costs of $\mathrm{CO}_{2}$ transport are between 2 and $15 \mathrm{US} \$ / \mathrm{t}_{\mathrm{CO} 2}$, depending on the pipeline capacity, type (onshore or offshore), and length $[14,15]$. The specific costs of $\mathrm{CO}_{2}$ storage are estimated between 1 and $18 \mathrm{US} \$ / \mathrm{t}_{\mathrm{CO} 2}$, depending on the storage type (depleted oil/gas field, geological formation, or ocean storage) and the potential of using EOR credits. The worldwide $\mathrm{CO}_{2}$ storage capacity is 400 billion tonnes in discovered capacities in oil and gas fields (depleted or for EOR projects) and 12,000 billion tonnes in potential (estimated) storage capacities in geological (saline) formations [16]. The $\mathrm{CO}_{2}$ storage capacities are such that exceeds the global net-zero emission scenario. It is estimated that the CCS industry would be cost-effective with carbon prices between 40 and $80 \mathrm{US} \$ / \mathrm{tCO}_{2}$ [11].

CCS technology offers vast potentials for $\mathrm{CO}_{2}$ reduction in the power industry, in the cement, iron, and steel production industries, and in the oil, natural gas, and chemical processing industries [17]. Different countries are developing their own legal and technical frameworks 
for future large-scale CCS implementation. Lee et al. $[18,19]$ stressed the importance of developing reliable methodologies for quantifying $\mathrm{CO}_{2}$ emission reduction through CCS at national basis. Nasirov et al. [20] analyzed decarbonization possibilities in developing countries and concluded that wind and solar energy are future of electricity generation, but still $15 \%$ of the electricity will be from coal by 2050. Kumar Shukla et al. [21] reviewed the clean coal potentials for the power industry in India. They concluded that post-combustion CCS is the solution for achieving a 30\% $\mathrm{CO}_{2}$ emission reduction by 2030 in India. Yun et al. [22] analyzed four scenarios for the power industry in South Korea. They concluded that the CCS coal scenario offers a good perspective in terms of greenhouse gases emissions control and electricity prices. Markewitz et al. [23] studied the potential of CCS technology for the cement industry, which contributes $5 \%$ of the global $\mathrm{CO}_{2}$ emissions. They concluded that CCS can remove $70-90 \%$ of the $\mathrm{CO}_{2}$ emissions from the cement industry in Germany at avoidance costs between 77 and $115 \mathrm{EUR} / \mathrm{t}_{\mathrm{CO} 2}$. Toktarova et al. [24] analyzed different pathways for the decarbonization of the steel industry in Sweden. They showed that top gas recycling blast furnaces and electric arc furnaces fitted with CCS technology could reduce $\mathrm{CO}_{2}$ emissions by $83 \%$ in 2045 . Adu et al. [25] studied the $\mathrm{CO}_{2}$ avoidance costs for post-combustion CCS technology integrated in coal-fired and natural gas combined cycle power plants. They concluded that, at $90 \% \mathrm{CO}_{2}$ capture efficiency, the $\mathrm{CO}_{2}$ avoidance costs are $\$ 72 / \mathrm{tCO}_{2}$ for the coal-fired plant and $\$ 94 / \mathrm{tCO}$ for the natural gas combined cycle.

CCS is an energy-intensive technology affecting substantially the plant performance. In coal-fired power plants, previous studies have reported net efficiency losses in the range between 7 and 11\%-pts [26-28] and electricity output penalties between 300 and $400 \mathrm{kWh} / \mathrm{t}_{\mathrm{CO} 2}$ [29]. Vu et al. [26] compared the techno-economical aspects of carbon capture on USC steam cycles with air-combustion and oxy-fuel combustion. They concluded that oxy-fuel CCS power plants offer an advantage over air-combustion CCS power plants. The net efficiency loss and levelized cost of electricity was 7\%-pts and $\$ 59 / \mathrm{MWh}$ in the first case, whereas $10 \%$-pts and $\$ 64 / \mathrm{MWh}$ in the second case. Liebenthal et al. [27] estimated the net efficiency loss at $10.94 \%$-pts for a CCS retrofit project on a supercritical power plant achieving $45.5 \%$ net efficiency at the design point. Li and Liang [30] assessed a CCS retrofit project for an existing USC power plant with $1000 \mathrm{MW}$ capacity and estimated the efficiency loss at $8.6 \%$-pts for $90 \%$ capture rate and $6 \%$-pts for a $50 \%$ capture rate. Xu et al. [31] estimated that modified boiler structures, waste heat recovery, and steam bleed turbines could be used to reduce the efficiency loss from $12.65 \%$ down to $8.79 \%$-pts Jackson and Brodal [32] found that the efficiency loss can be reduced through the optimization of the CCS compression process. Compressor designs with multiple impellers per stage and variable pressure ratios are proposed.

The previous research is mainly focused on the performance analysis of CCS retrofit projects for coal-fired power plants. The present study makes a step forward by assessing the impact of CCS technology on four different generations of coal-fired power plants including the subcritical (SUBC), the supercritical (SC), the ultra-supercritical (USC), and the advanced ultra-supercritical (A-USC) steam cycle using performance simulation analysis. The simulation approach consists of using appropriate mass and energy balance equations to the power plant components. The obtained results from the simulation code are validated against results found in the literature. Particular attention is given to the power plant-CCS interface quantities and their effects on the efficiency loss and electricity penalty. The performance of the A-USC power plant is assessed through the combined effects of reboiler heating duty and temperature, the compression and intercooling strategy, and the advanced heat integration. The analysis is concluded with the comparison between the performance of present-state and future upgraded CCS technology.

\section{Methodology}

\subsection{The Reference Steam Cycle}

In the present study, a coal-fired power plant with net electricity capacity of $700 \mathrm{MW}$ is selected as the reference power plant without CCS. The analyzed steam cycle configuration 
comprises a single-stage reheat and eight feedwater heaters (FWH), as shown in Figure 1. Steam cycle configurations with double reheat and nine or more feedwater heaters are also possible. The double reheat steam cycle would increase the thermal efficiency by an additional $1 \%$ but at added capital and maintenance costs [33,34]. Four feedwater heaters (FWH 1-4) are placed at the high-pressure side while three feedwater heaters (FWH 5-7) and the deaerator are placed at the low-pressure side. The electricity generation unit includes a high-pressure (HP) turbine, an intermediate pressure (IP), two double-flow low pressure (LP) turbines and the electric generator. Superheated steam enters the HP turbine at state (1) and expands to state (3). The cold reheat (5) is brought into the boiler reheat section and enters the IP turbine at state (6). In the IP turbine, steam expands to state (10) and is brought to the LP turbines where it expands to state (17). The steam quality in the exhaust state (17) is around 0.9 and depends on the reheat pressure in (6). The cycle thermal efficiency could be increased by raising the reheat pressure at the expense of lower steam qualities and accelerated erosion in the last stages of the LP turbines. In the present analysis, the reheat pressure is limited at one-fifth of the main steam pressure in order to avoid exhaust steam qualities below 0.88 . In the condenser, the exhaust steam is turned into liquid water (18). The condensate pump (CP) sends water to the low pressure FWHs (19). In the three LP FWHs, the condensate water is subsequently heated to states (21), (23), and (25). The deaerator removes dissolved gases from the feedwater and feeds the feedwater pump (FWP). The FWP provides the necessary water head (28) while overcoming the pressure drops in the high-pressure FWHs and in the boiler. The FWP is driven by the feedwater pump turbine (FWPT) running on steam extraction (11). The exhaust steam from the FWPT (34) is sent to the condenser. The condenser pressure is 0.04 bar, corresponding to coolant inlet and outlet temperatures of $17^{\circ} \mathrm{C}$ (39) and $25^{\circ} \mathrm{C}$ (40). After the FWP, feedwater is preheated to states (30, (32), (34, and (36) as it passes the four HP FWHs. The FWHs are shell-and-tubes heat exchangers where feedwater is heated by extracted steam (2), (4), (7), (8), (9), (14), (15), and (16). The deaerator is a direct-contact heat exchanger where feedwater (26) is heated by the extracted steam (9) and the subcooled condensate (29).

The steam cycle performance is analyzed through four generations of coal-fired power plants. Each next generation represents an improvement over the previous one in terms of efficiency and $\mathrm{CO}_{2}$ emissions. The first steam cycle corresponds to a subcritical power plant (SUBC) with superheat/reheat steam temperatures of $540 / 540{ }^{\circ} \mathrm{C}$ and preheat/reheat steam pressures of $170 / 35$ bar. The second cycle refers to a supercritical power plant (SC) with steam temperatures of $580 / 580{ }^{\circ} \mathrm{C}$ and pressures of $250 / 50$ bar. The third cycle is a modern ultra-supercritical power plant (USC) with increased steam temperatures $600 / 610{ }^{\circ} \mathrm{C}$ and pressures 300/60 bar. The fourth steam cycle corresponds to the future planned advanced ultra-supercritical power plant (A-USC) with even higher steam temperatures $700 / 720{ }^{\circ} \mathrm{C}$ and pressures 350/75 bar. The SC, USC, and A-USC power plants operate with an IP/LP crossover pressure of 4 bar, a planned design feature, representing the $\mathrm{CO}_{2}$ capture-readiness of these steam cycles. The SUBC power plant operates at a higher IP/LP crossover pressure of 7.5 bar, which still offers the possibility of CCS retrofit. The four steam cycles use the same condenser pressure of 0.04 bar and utilize the same type of coal. The basic steam conditions are given in Table 1 and the coal composition is reported in Table 2.

The turbine isentropic efficiency, including inlet valve losses, is 0.90 for HP turbine, 0.94 for IP turbine, and 0.885 for LP turbine [33]. The FWP efficiency is 0.85 and the CP efficiency is 0.80 [35]. The pressure drop in the steam generator is 50 bar for main steam and 5 bar for reheat steam [33]. The pressure drop in steam pipes is 0.03 , expressed as a fraction of inlet steam pressure. The outlet temperature of the subcooled liquid condensate is $5 \mathrm{~K}$ above the feedwater inlet temperature [36]. The feedwater outlet temperature is $2 \mathrm{~K}$ below the steam saturation temperature. The drive power to feedwater and condensate pumps is supplied by a feedwater pump turbine (FWPT) running on steam bled from the IP/LP crossover. The efficiency of the steam generator is 0.949 based on fuel LHV. The electric generator efficiency is 0.988 and the mechanical efficiency is 0.99 [34]. The net efficiency of the analyzed steam cycle configuration is maximized by optimizing the quantity and pressure of the nine steam 
extractions. A general approach is to distribute the feedwater heating range into equivalent enthalpy increments among the FWHs $[36,37]$. Water and steam properties are calculated using the IAPWS-IF97 standard built in the CoolProp database.

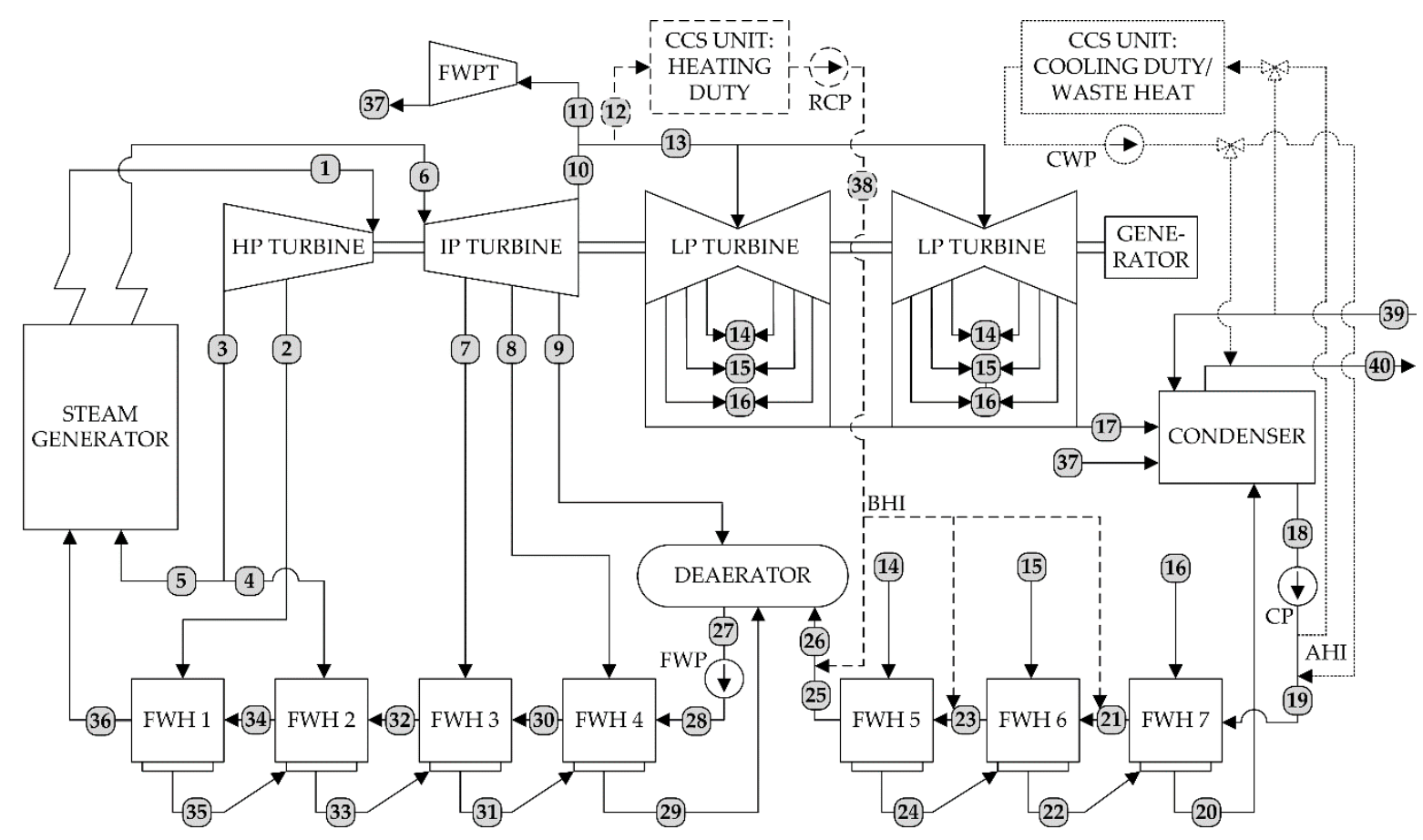

Figure 1. The analyzed steam cycle configuration. The dashed and dotted components are present only in the carbon capture and storage (CCS) integrated steam cycle and represent the CCS heating and cooling duties with the respective basic (BHI) and advanced heat integration (AHI).

Table 1. Basic input parameters for the analyzed steam cycle.

\begin{tabular}{lcccc}
\hline \multicolumn{1}{c}{ Steam Conditions } & SUBC & SC & USC & A-USC \\
\hline Superheat temperature, ${ }^{\circ} \mathrm{C}$ & 540 & 580 & 600 & 700 \\
Superheat pressure, bar & 170 & 250 & 300 & 350 \\
Reheat temperature, ${ }^{\circ} \mathrm{C}$ & 540 & 580 & 610 & 720 \\
Reheat pressure, bar & 35 & 50 & 60 & 75 \\
IP/LP crossover pressure, bar & 7.5 & 4 & 4 & 4 \\
Condenser pressure, bar & 0.04 & 0.04 & 0.04 & 0.04 \\
\hline
\end{tabular}

Table 2. Ultimate analysis of bituminous coal.

\begin{tabular}{lc}
\hline Carbon $(\mathrm{C}), \%$ & 65.90 \\
Hydrogen (H), \% & 4.30 \\
Oxygen (C), \% & 8.00 \\
Nitrogen (N), \% & 1.40 \\
Sulphur (C), \% & 1.00 \\
Ash, \% & 11.7 \\
Moisture, \% & 7.7 \\
Low heating calorific value (LHV), MJ/kg & 26.3 \\
\hline
\end{tabular}

\subsection{The CCS Integrated Steam Cycle}

The post-combustion CCS unit is fitted into the flue gas line along with the other treatment units (electro-static precipitator, DeNOx and DeSOx). Flue gases are directed into the absorber column, where the cold solvent forms a rich solution by absorbing $\mathrm{CO}_{2}$. The carbon-free flue gases are discharged into the atmosphere through the stack. Before solvent regeneration in the stripper, the rich solution is preheated in the lean/rich solution heat recuperator. Inside the stripper, the rich solution is separated into lean solution and wet $\mathrm{CO}_{2}$. The lean solution is sent back to the absorber through the heat recuperator. On the other side, moisture is removed from $\mathrm{CO}_{2}$ in the moisture separator (overhead 
condenser) and dry $\mathrm{CO}_{2}$ is compressed in an 8-stage compression process (CS 1-CS 8). Between compression stages, $\mathrm{CO}_{2}$ temperature is decreased in water cooled intercoolers (IC 1-IC 7). High-pressure $\mathrm{CO}_{2}$ is fed into the pipeline and transported to permanent storage, enhanced oil recovery, or industrial use. The heating demand needed in the solvent reboiler is supplied by low-pressure steam extracted from the IP/LP crossover pipe (9). The schematic diagram of the amine-based CCS unit is shown in Figure 2. The present study does not perform a detailed chemistry simulation of the $\mathrm{CO}_{2}$ absorption process, rather it studies how the CCS unit affects the performance of the coal-fired power plant. To this end, a wide range of interface quantities between the CCS unit and the steam cycle was assumed, reflecting different types of $\mathrm{CO}_{2}$ absorbents and CCS processes. Specifically, the reboiler heating duty necessary for solvent regeneration is assumed in the range between 1.5 and $5.0 \mathrm{MJ}_{\mathrm{th}} / \mathrm{kg}_{\mathrm{CO} 2}$ [38]. The cooling duty, which encompasses the cooling demands for moisture separation, feed gases cooling, lean amine cooling, and $\mathrm{CO}_{2}$ compression intercooling, is assumed between 2.3 and $6.3 \mathrm{MJ}$ th $/ \mathrm{kg}_{\mathrm{CO} 2}$ [29]. The auxiliary power duty needed for the operation of cooling water pumps, flue gases fans, and solvent pumps is assumed between 0.07 and $0.21 \mathrm{MJ}_{\mathrm{el}} / \mathrm{kg}_{\mathrm{CO} 2}$ [27]. The above CCS energy requirements correspond to absorber temperatures between 30 and $50{ }^{\circ} \mathrm{C}$ and absorber pressures of around 1 bar [38], stripper (desorber) temperatures between 80 and $160{ }^{\circ} \mathrm{C}$ and stripper pressures between 1 and $10 \mathrm{bar}$, [27], L/G (liquid-to-gas ratio) ratios between 2 and $6 \mathrm{~kg} / \mathrm{kg}$ [38], lean solution loading between 0.05 and $0.3 \mathrm{~mol} / \mathrm{mol}$, and rich solution loading between 0.3 and $0.6 \mathrm{~mol} / \mathrm{mol}$ [39]. The exact CCS operation parameters cannot be determined without running a full chemistry simulation of the CCS unit, which is beyond the scope of the present study.

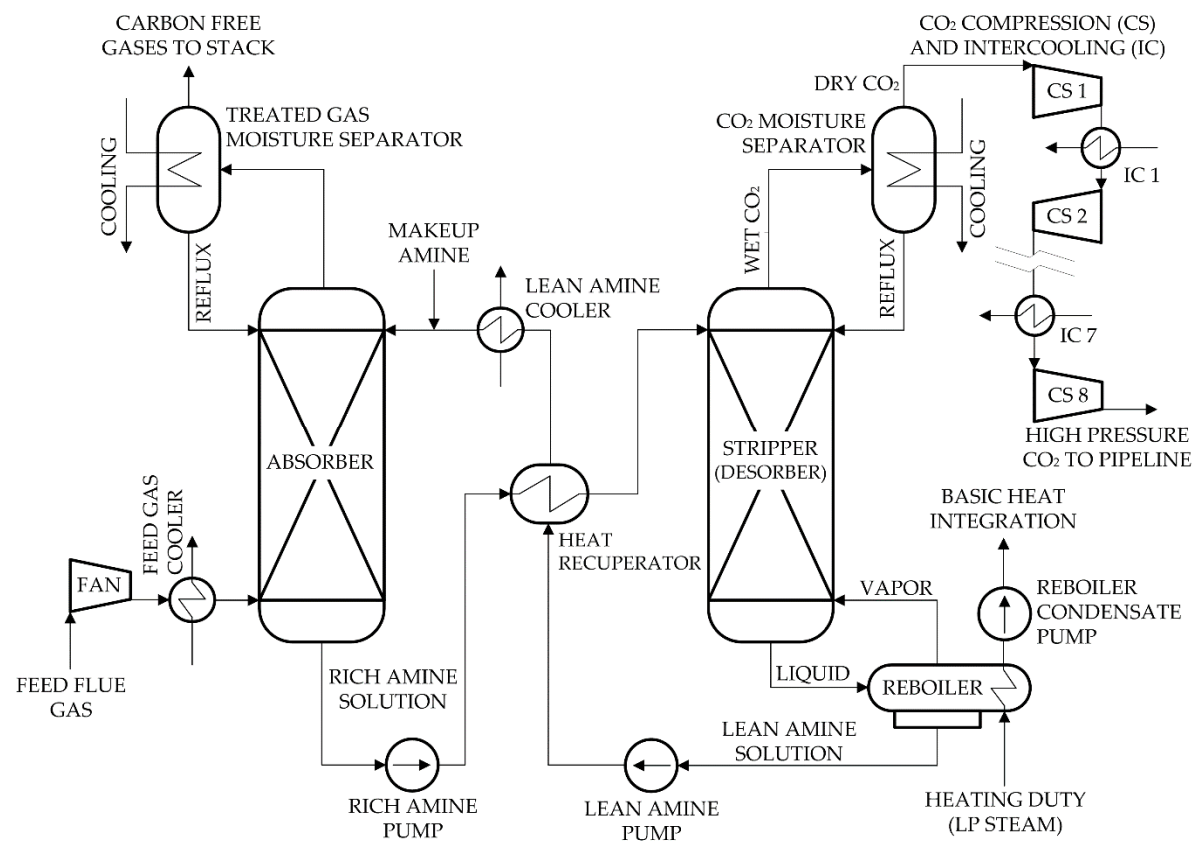

Figure 2. The schematic diagram of the amine-based CCS unit.

The CCS unit greatly affects the performance and the efficiency of the power plant. Carbon capture-ready steam cycles (SC, USC, and A-USC) employ an IP/LP pressure of $4 \mathrm{bar}$, matching reboiler temperatures of $120-140{ }^{\circ} \mathrm{C}$. On the other hand, the CCS retrofitted SUBC steam cycle uses throttles and pressure-maintaining valves to control the steam condition in the IP/LP crossover, which leads to increased electricity penalties [35]. $\mathrm{CO}_{2}$ compression is the second largest energy consumer in the CCS unit with power demands of $0.30-0.35 \mathrm{MJ} \mathrm{Jl}_{\mathrm{el}} / \mathrm{kg}_{\mathrm{CO} 2}$ [38]. Because steam is extracted from the main cycle, the condenser thermal load reduces but the overall thermal discharge increases since heat is removed both from the $\mathrm{CO}_{2}$ capture process and from $\mathrm{CO}_{2}$ compression. For example, in a state-of-the-art CCS unit with $30 \mathrm{wt} \% \mathrm{mo}-$ 
noethanolamine (MEA), the heating duty is $3.5 \mathrm{MJ}_{\mathrm{th}} / \mathrm{kg}_{\mathrm{CO} 2}$, the cooling duty is $4.6 \mathrm{MJ} \mathrm{th}_{\mathrm{th}} / \mathrm{kg}_{\mathrm{CO} 2}$, and the auxiliary power duty for cooling water pumps, solvent pumps, and gas blowers is $0.15 \mathrm{MJ}$ el $/ \mathrm{kg}_{\mathrm{CO} 2}\left(\mathrm{CO}_{2}\right.$ compression excluded), estimated from correlations in [27].

Basic heat reintegration (BHI: Dashed lines in Figure 1) is achieved by returning the reboiler condensate (38) into the LP feedwater preheating line respecting the temperature level. The exact injection point depends on the temperature in the reboiler. For the analyzed steam cycle configuration, there are three possible injection points: (1) Between FWH5 and deaerator for reboiler temperatures higher than $130{ }^{\circ} \mathrm{C},(2)$ between FWH5 and FWH6 for reboiler temperatures in the range between $100{ }^{\circ} \mathrm{C}$ and $130^{\circ} \mathrm{C}$, and (3) between FWH6 and FWH7 for reboiler temperatures below $100{ }^{\circ} \mathrm{C}$. Advanced heat integration (AHI: dotted lines in Figure 1) consists of redirecting the LP condensate towards $\mathrm{CO}_{2}$ intercoolers and the overhead condenser to recycle the low temperature waste heat available in the CCS unit. When the LP feedwater preheating line cannot allocate the entire quantity of waste heat, the cooling system removes the excessive waste heat from the CCS unit.

\subsection{Thermal Efficiency and Electricity Output Penalty}

The principal input parameters for steam cycle calculations are the net electric power $N_{\text {el,net,ref }}$ of the reference steam cycle $(700 \mathrm{MW})$, the steam conditions in Table 1 , and the coal composition in Table 2. The gross electric power $N_{\text {el,gross,ref }}$ is obtained adding auxiliary power consumption $N_{\mathrm{el} \text {,aux,ref }}$ to the net electric power. In the present study, the auxiliary power is estimated at $35 \mathrm{MW}$, that is $5 \%$ of net electric power $(700 \mathrm{MW})$. The auxiliary power consumers are primary air and combustion air fans, cooling tower fans, mill grinders, flue gases fans, flue gas treatment (desulfurization, electrostatic precipitators, DeNOx treatment), condensate pumps, circulating water pumps, water treatment, and ash handling. The FWP is not accounted in the auxiliary power duty since it is turbine-driven and provided for by a separate steam extraction from the IP/LP crossover (Figure 1.)

$$
N_{\mathrm{el}, \text { gross,ref }}=N_{\mathrm{el}, \text { net,ref }}+N_{\mathrm{el}, \text { aux }, \text { ref }}
$$

The live steam mass flow rate is determined from the gross electric power and the mechanical work of the HP, IP, and LP turbines, augmented by mechanical $\left(\eta_{\mathrm{m}}\right)$ and generator $\left(\eta_{\mathrm{g}}\right)$ losses

$$
\dot{m}_{\text {steam }}=\frac{N_{\text {el,gross,ref }}}{\eta_{\mathrm{g}} \eta_{\mathrm{m}} \sum_{i}\left(1-\sum_{j} \varepsilon_{j}\right)\left(h_{i-1}-h_{i}\right)}
$$

The live steam mass flow rate $\dot{m}_{\text {steam }}$ is subsequently reduced by the steam extractions $\varepsilon_{\mathrm{j}}$. Note that the steam cycle configuration shown in Figure 1 contains a total of 10 possible steam extractions, including the FWPT extraction $\left(\varepsilon_{11}\right)$ and the CCS extraction $\left(\varepsilon_{12}\right)$. The CCS extraction is $\varepsilon_{12}=0$ in the reference steam cycle and $\varepsilon_{12}>0$ in the CCS integrated steam cycle. The enthalpy difference $\left(h_{\mathrm{i}-1}-h_{\mathrm{i}}\right)$ refers to the actual enthalpy drop obtained as the product of the isentropic enthalpy drop and the turbine isentropic efficiency. The fuel heat input (LHV) is determined from superheat and reheat duties, and taking into account the steam generator efficiency $\eta_{\mathrm{sg}}$

$$
\dot{Q}_{\text {fuel,LHV }}=\frac{\dot{Q}_{\text {superheat }}+\dot{Q}_{\text {reheat }}}{\eta_{\text {sg }}}=\frac{\dot{m}_{\text {steam }}\left(h_{1}-h_{36}\right)+\dot{m}_{\text {steam }}\left(1-\varepsilon_{2}-\varepsilon_{4}\right)\left(h_{6}-h_{5}\right)}{\eta_{\text {sg }}}
$$

The reference power plant gross efficiency $\eta_{\text {gross,ref }}$ is obtained dividing the gross electric power by the LHV-based fuel heat input $\dot{Q}_{\text {fuel,LHV }}$

$$
\eta_{\text {gross,ref }}=\frac{N_{\text {el,gross,ref }}}{\dot{Q}_{\text {fuel,LHV }}}
$$


The net efficiency $\eta_{\text {net,ref }}$ is obtained dividing the net electric power (1) by the fuel heat input (3)

$$
\eta_{\text {net,ref }}=\frac{N_{\text {el,net,ref }}}{\dot{Q}_{\text {fuel,LHV }}}
$$

The gross electric output in the CCS integrated steam cycle $N_{\text {el,gross,CCS }}$ is reduced due to the steam extraction supplying the thermal duty to the CCS unit.

$$
N_{\mathrm{el}, \text { gross, CCS }}=N_{\mathrm{el}, \text { gross,ref }}-\Delta N_{\mathrm{el} \text {,gross }}
$$

The power loss factor $\sigma$ is the ratio between the gross electric power loss $\Delta N_{\text {el,gross }}$ and the extracted steam heat flow $\dot{Q}_{\text {steam,CCS }}$

$$
\sigma=\frac{\Delta N_{\mathrm{el}, \text { gross }}}{\dot{\mathrm{Q}}_{\text {steam,CCS }}}
$$

The gross efficiency $\eta_{\text {gross,CCS }}$ of the CCS integrated power plant is then

$$
\eta_{\text {gross,CCS }}=\frac{N_{\text {el,gross,CCS }}}{\dot{Q}_{\text {fuel,LHV }}}
$$

The net electric output of the CCS integrated power plant $N_{\mathrm{el}, \text { net,CCS }}$ is obtained from its gross electric output reduced by the auxiliary power consumption of the reference steam cycle and the auxiliary power consumption in the CCS unit

$$
N_{\mathrm{el}, \mathrm{net}, \mathrm{CCS}}=N_{\mathrm{el} \text {,gross,CCS }}-N_{\mathrm{el}, \mathrm{aux}, \mathrm{ref}}-N_{\mathrm{el}, \mathrm{aux}, \mathrm{CCS}}
$$

The CCS auxiliary power comprises the $\mathrm{CO}_{2}$ compression power duty and the parasitic power consumption for $\mathrm{CO}_{2}$ capture, in cooling water pumps, solvent pumps, and flue gases fan

$$
N_{\mathrm{el}, \mathrm{aux}, \mathrm{CCS}}=\dot{m}_{\mathrm{CO}_{2}} \sum_{i=1}^{8} \frac{h_{i}-h_{i-1}}{\eta_{\mathrm{comp}}}+\dot{m}_{\mathrm{CO}_{2}} \cdot w_{\mathrm{el}, \mathrm{CCS}}
$$

The captured $\mathrm{CO}_{2}$ mass flow rate $\dot{m}_{\mathrm{CO} 2}$ is obtained assuming a $\mathrm{CO}_{2}$ capture rate of 0.9 in the absorber. The $\mathrm{CO}_{2}$ compression efficiency is $\eta_{\text {comp }}=0.80$. An eight-stage compression with intercooling between stages and a final $\mathrm{CO}_{2}$ pressure of 150 bar are assumed as the baseline compression scenario. The specific parasitic consumption of the other electric consumers is assumed $w_{\mathrm{el}, \mathrm{CCS}}=0.15 \mathrm{MJ} \mathrm{el} / \mathrm{kgCO}_{\mathrm{C}}$. The CCS-integrated power plant net thermal efficiency $\eta_{\text {net,CCS }}$ is defined as the ratio between the net electric power in the CCS power plant and the LHV-based fuel heat input

$$
\eta_{\text {net,CCS }}=\frac{N_{\text {el,net,CCS }}}{\dot{Q}_{\text {fuel,LHV }}}
$$

The efficiency penalty caused by the CCS unit to the coal-fired power plant is determined as

$$
\Delta \eta_{\text {net }}=\eta_{\text {net,ref }}-\eta_{\text {net,CCS }}
$$

The electricity output penalty (EOP) of the CCS integrated power plant is a measure of performance loss caused from the CCS unit. It is calculated as ratio of the net electricity power loss and the mass flow rate of captured and compressed $\mathrm{CO}_{2}$.

$$
\mathrm{EOP}=\frac{N_{\mathrm{el}, \text { net,ref }}-N_{\mathrm{el}, \text { net,CCS }}}{\dot{m}_{\mathrm{CO}_{2}}}
$$




\subsection{Thermodynamic Calculations}

The thermodynamic analysis of the coal-fired power plant integrated with CCS technology was carried out using a simulation code written in the programming language Visual Basic for Applications (VBA), version 7.1, whereas the host application is MS Excel. The fluid physical properties are obtained from the CoolProp wrapper (subroutine) functions available for MS Excel. The steam cycle components- the steam generator, the turbines, the condenser, the feedwater heaters (FWH 1-FWH 7), the deaerator, the feedwater pump (FWP), the condensate pump (CP), the feedwater pump turbine (FWPT), and the basic (BHI) and the advanced (AHI) heat integrations are modelled using the control volume approach. Each control volume is described with the appropriate mass and energy conservation equations and neglecting heat losses towards the surrounding. The mass relations equate the sum of inlet streams mass rates to the sum of outlet streams mass rates. The energy relations equate the sum of inlet streams total enthalpies to the sum of outlet streams total enthalpies, taking into account the added or the extracted heat rates $(\dot{Q})$ and the added or the extracted work rates $(W)$ in the observed control volumes. Table 3 lists the mass and energy conservation equations for all the component in the steam cycle. The systems of mass and energy conservation equations can be solved once the steam cycle input parameters are defined. The steam cycle input parameters comprise the steam superheat pressure and temperature, the steam reheat pressure and temperature, the condenser pressure, and the IP/LP crossover pressure, with the values reported in Table 1. The input parameters enable to calculate the steam superheat enthalpy $\left(h_{1}\right)$, the reheat steam enthalpy $\left(h_{6}\right)$, the steam enthalpies in the IP/LP crossover $\left(h_{10}=h_{11}=h_{12}=h_{13}\right)$, and the enthalpy of liquid water from the condenser $\left(h_{18}\right)$. The live steam mass flow rate $\left(\dot{m}_{1}\right)$ is obtained from equation (2), taking that the net electric capacity of the reference steam cycle is $700 \mathrm{MW}$ and assuming steady-state operation. The steam extraction enthalpies $\left(h_{2}, h_{3}, h_{7}\right.$, $h_{8}, h_{9}, h_{14}, h_{15}$, and $\left.h_{16}\right)$ are calculated assuming equally distributed enthalpy increments in the FWHs, a strategy yielding maximum thermal efficiency in steam cycles $[36,37]$. The steam extraction ratios $\left(\varepsilon_{2}, \varepsilon_{3}, \varepsilon_{7}, \varepsilon_{8}, \varepsilon_{9}, \varepsilon_{14}, \varepsilon_{15}\right.$, and $\left.\varepsilon_{16}\right)$, are obtained as the ratios between the extracted steam mass rates $\left(\dot{m}_{2}, \dot{m}_{3}, \dot{m}_{7}, \dot{m}_{8}, \dot{m}_{9}, \dot{m}_{14}, \dot{m}_{15}\right.$, and $\left.\dot{m}_{16}\right)$ and the live steam mass rate $\left(\dot{m}_{1}\right)$, using mass and energy relations for FWH 1-7 and the deaerator.

Table 3. Mass and energy conservation equations for the steam cycle components.

\begin{tabular}{|c|c|c|}
\hline Component & Mass Equation & Energy Equation \\
\hline Steam superheat & $\dot{m}_{36}=\dot{m}_{1}$ & $\dot{m}_{36} h_{36}+\dot{Q}_{\text {superheat }}=\dot{m}_{1} h_{1}$ \\
\hline Steam reheat & $\dot{m}_{5}=\dot{m}_{6}$ & $\dot{m}_{5} h_{5}+\dot{Q}_{\text {reheat }}=\dot{m}_{6} h_{6}$ \\
\hline HP turbine & $\dot{m}_{1}=\dot{m}_{2}+\dot{m}_{3}$ & $\dot{m}_{1} h_{1}=\dot{m}_{2} h_{2}+\dot{m}_{3} h_{3}+W_{\mathrm{T}, \mathrm{HP}}$ \\
\hline IP turbine & $\dot{m}_{6}=\dot{m}_{7}+\dot{m}_{8}+\dot{m}_{9}+\dot{m}_{10}$ & $\dot{m}_{6} h_{6}=\dot{m}_{7} h_{7}+\dot{m}_{8} h_{8}+\dot{m}_{9} h_{9}+\dot{m}_{10} h_{10}+W_{\mathrm{T}, \mathrm{IP}}$ \\
\hline IP/LP extraction & $\dot{m}_{10}=\dot{m}_{11}+\dot{m}_{12}+\dot{m}_{13}$ & $\dot{m}_{10} h_{10}=\dot{m}_{11} h_{11}+\dot{m}_{12} h_{12}+\dot{m}_{13} h_{13}$ \\
\hline BHI (with CCS) & $\dot{m}_{12}=\dot{m}_{38(\mathrm{BHI})}$ & $\dot{m}_{12} h_{12}+W_{\mathrm{RCP}}=Q_{\mathrm{CCS}, \text { heating }}+\dot{m}_{38(\mathrm{BHI})} h_{38(\mathrm{BHI})}$ \\
\hline LP turbine & $\dot{m}_{13}=\dot{m}_{14}+\dot{m}_{15}+\dot{m}_{16}+\dot{m}_{17}$ & $\dot{m}_{13} h_{13}=\dot{m}_{14} h_{14}+\dot{m}_{15} h_{15}+\dot{m}_{16} h_{16}+\dot{m}_{17} h_{17}+W_{\mathrm{T}, \mathrm{LP}}$ \\
\hline Condenser & $\dot{m}_{17}+\dot{m}_{20}+\dot{m}_{37}=\dot{m}_{18}$ & $\dot{m}_{17} h_{17}+\dot{m}_{20} h_{20}+\dot{m}_{37} h_{37}=\dot{m}_{18} h_{18}+\dot{Q}_{\text {condenser }}$ \\
\hline $\mathrm{CP}$ & $\dot{m}_{18}=\dot{m}_{19}$ & $\dot{m}_{18} h_{18}+W_{\mathrm{CP}}=\dot{m}_{19} h_{19}$ \\
\hline AHI (with CCS) & $\dot{m}_{18}=\dot{m}_{19}(\mathrm{AHI})$ & $\dot{m}_{18} h_{18}+W_{\mathrm{CWP}}+Q_{\mathrm{CCS}, \text { cooling }}=\dot{m}_{19(\mathrm{AHI})} h_{19(\mathrm{AHI})}$ \\
\hline FWH 7 & $\dot{m}_{16}+\dot{m}_{19}+\dot{m}_{22}=\dot{m}_{20}+\dot{m}_{21}$ & $\dot{m}_{16} h_{16}+\dot{m}_{19} h_{19}+\dot{m}_{22} h_{22}=\dot{m}_{20} h_{20}+\dot{m}_{21} h_{21}$ \\
\hline FWH 6 & $\dot{m}_{15}+\dot{m}_{21}+\dot{m}_{24}=\dot{m}_{22}+\dot{m}_{23}$ & $\dot{m}_{15} h_{15}+\dot{m}_{21} h_{21}+\dot{m}_{24} h_{24}+\dot{m}_{\mathrm{BHI}} h_{\mathrm{BHI}}=\dot{m}_{22} h_{22}+\dot{m}_{23} h_{23}$ \\
\hline FWH 5 & $\dot{m}_{14}+\dot{m}_{23}=\dot{m}_{24}+\dot{m}_{25}$ & $\dot{m}_{14} h_{14}+\dot{m}_{23} h_{23}+\dot{m}_{\mathrm{BHI}} h_{\mathrm{BHI}}=\dot{m}_{24} h_{24}+\dot{m}_{25} h_{25}$ \\
\hline Deaerator & $\dot{m}_{9}+\dot{m}_{26}+\dot{m}_{29}=\dot{m}_{27}$ & $\dot{m}_{9} h_{9}+\dot{m}_{25} h_{25}+\dot{m}_{29} h_{29}+\dot{m}_{\mathrm{BHI}} h_{\mathrm{BHI}}=\dot{m}_{27} h_{27}$ \\
\hline FWP & $\dot{m}_{27}=\dot{m}_{28}$ & $\dot{m}_{27} h_{27}+W_{\mathrm{FWP}}=\dot{m}_{28} h_{28}$ \\
\hline FWPT & $\dot{m}_{11}=\dot{m}_{37}$ & $\dot{m}_{11} h_{11}=\dot{m}_{37} h_{37}+W_{\mathrm{FWPT}}$ \\
\hline FWH 4 & $\dot{m}_{8}+\dot{m}_{28}+\dot{m}_{31}=\dot{m}_{29}+\dot{m}_{30}$ & $\dot{m}_{8} h_{8}+\dot{m}_{28} h_{28}+\dot{m}_{31} h_{31}=\dot{m}_{29} h_{29}+\dot{m}_{30} h_{30}$ \\
\hline FWH 3 & $\dot{m}_{7}+\dot{m}_{30}+\dot{m}_{33}=\dot{m}_{31}+\dot{m}_{32}$ & $\dot{m}_{7} h_{7}+\dot{m}_{30} h_{30}+\dot{m}_{33} h_{33}=\dot{m}_{31} h_{31}+\dot{m}_{32} h_{32}$ \\
\hline FWH 2 & $\dot{m}_{4}+\dot{m}_{32}+\dot{m}_{35}=\dot{m}_{33}+\dot{m}_{34}$ & $\dot{m}_{4} h_{4}+\dot{m}_{32} h_{32}+\dot{m}_{35} h_{35}=\dot{m}_{33} h_{33}+\dot{m}_{34} h_{34}$ \\
\hline FWH 1 & $\dot{m}_{2}+\dot{m}_{34}=\dot{m}_{35}+\dot{m}_{36}$ & $\dot{m}_{2} h_{2}+\dot{m}_{34} h_{34}=\dot{m}_{35} h_{35}+\dot{m}_{36} h_{36}$ \\
\hline
\end{tabular}




\section{Results and Discussion}

\subsection{Steam Cycle Validation}

The calculated net efficiency in the reference steam cycle is compared against results found in the literature. Table 4 reports the steam cycle type and the basic steam input parameters: Superheat and reheat temperatures (S/R T) and pressures (S/R P). The studies referenced in Table 4 use different inputs for the same parameters: Turbine efficiency, generator efficiency, boiler efficiency, approach temperatures, mechanical losses, steam pressure drops, auxiliary power consumption, and other, all affecting the final net efficiency results. The validation is carried out by taking into account all the available input values found in the referenced studies and assuming those not provided. For example, steam cycles \#1, \#2, and \#3 are ultra-supercritical (USC) steam cycles with similar steam conditions. However, the range of the reported net efficiencies is larger than 3.7 percentage points. This is because of different input values for the same steam cycle parameters and, especially, because of different approaches to auxiliary power consumption. Specifically, steam cycles \#1 and \#3 assume an auxiliary power consumption of 5-6\% while steam cycle \#2 completely neglects it. Aiming for a fair validation, the present study includes auxiliary power consumption in all the steam cycles, except when validating against steam cycle \#2. Overall, the present methodology for steam cycle calculations provides reliable results and is applied for further analysis.

Table 4. Steam cycle validation against results found in the literature.

\begin{tabular}{cccccc}
\hline \multicolumn{2}{c}{ Steam Cycle } & \multicolumn{2}{c}{ Input Parameters } & \multicolumn{2}{c}{ Net Efficiency } \\
\hline$\#$ & Type & S/R T & S/R P & Ref. No & Present Study \\
\hline 1 & USC & $600 / 620^{\circ} \mathrm{C}$ & $285 / 60 \mathrm{bar}$ & $45.49 \%[27]$ & $45.21 \%$ \\
2 & USC & $650 / 670^{\circ} \mathrm{C}$ & $300 / 70 \mathrm{bar}$ & $47.58 \%[40]^{*}$ & $47.40 \%{ }^{*}$ \\
3 & USC & $590 / 610^{\circ} \mathrm{C}$ & $300 / 57 \mathrm{bar}$ & $43.84 \%[41]$ & $44.15 \%$ \\
4 & A-USC & $733 / 760^{\circ} \mathrm{C}$ & $242.3 / 51 \mathrm{bar}$ & $44.87 \%[42]$ & $44.72 \%$ \\
5 & A-USC & $680 / 700^{\circ} \mathrm{C}$ & $352 / 73.5 \mathrm{bar}$ & $46.31 \%[33]$ & $46.63 \%$ \\
\hline
\end{tabular}

* Auxiliary power consumption excluded.

\subsection{The Reference Steam Cycle}

The steam cycle configuration in Figure 1 is analyzed for four different steam cycle conditions. This section presents a detailed analysis of the reference A-USC cycle with the most advanced steam parameters, corresponding to future planned coal-fired power plants. The temperature-entropy chart of the reference A-USC steam cycle is shown in Figure 3. The main feature of supercritical steam cycles (SC, USC, and A-USC) is steam superheat occurring above the saturation curves and the critical point of water (36) $\rightarrow$ (1)). Only in the case of a subcritical steam cycle (SUBC), the process (36) $\rightarrow$ (1) enters the phase change dome, under the CP. The chart in Figure 3 uses bold lines for the main steam cycle processes, dashed lines for steam extractions, and dotted lines for saturation curves. A total of eight extractions supplying steam to the deaerator and FWHs are shown in Figure 3. Extraction (11) supplies steam from the IP/LP crossover to the FWPT. It is at the same state that steam would be extracted (12) in case of a CCS integrated steam cycle. The characteristic points in Figure 3 follows the labels given by the scheme in Figure 1. For the A-USC steam cycle, the turbines generate a gross useful work of $751.5 \mathrm{MW}$ : HP turbine 219.2 MW, IP turbine $342.3 \mathrm{MW}$, and LP turbines 190.0 MW. The power plant gross electric power is $735 \mathrm{MW}$ while the net electric power transmitted to the grid is $700 \mathrm{MW}$, at full load. The fuel heat input $1469.5 \mathrm{MW}$, which returns a gross electric efficiency of $50.02 \%$ and a net electric efficiency of $47.64 \%$.

Table 5 reports the A-USC steam cycle data in terms of steam mass flow rate $(\dot{m})$, temperature $(T)$, and pressure $(p)$ in the characteristic points. Table 6 shows the results in the four reference steam cycles obtained using the steam conditions reported in Table 1 and the input parameters discussed in Section 2.1. The results show that supercritical power plants (SC, USC, A-USC) achieve increased thermal efficiency with lower $\mathrm{CO}_{2}$ emissions 
when compared to subcritical power plants (SUBC). The net efficiency difference between the SUBC and the A-USC steam cycle is slightly less than 8 percentage points while $\mathrm{CO}_{2}$ emissions are reduced by $16.5 \%$. Still, the A-USC power plant emits around $700 \mathrm{~kg} / \mathrm{MWh}_{\mathrm{el}}$ of $\mathrm{CO}_{2}$ per unit of generated electricity, which converts into 3.4 million tonnes of $\mathrm{CO}_{2}$ for 7000 full-load hours per year.

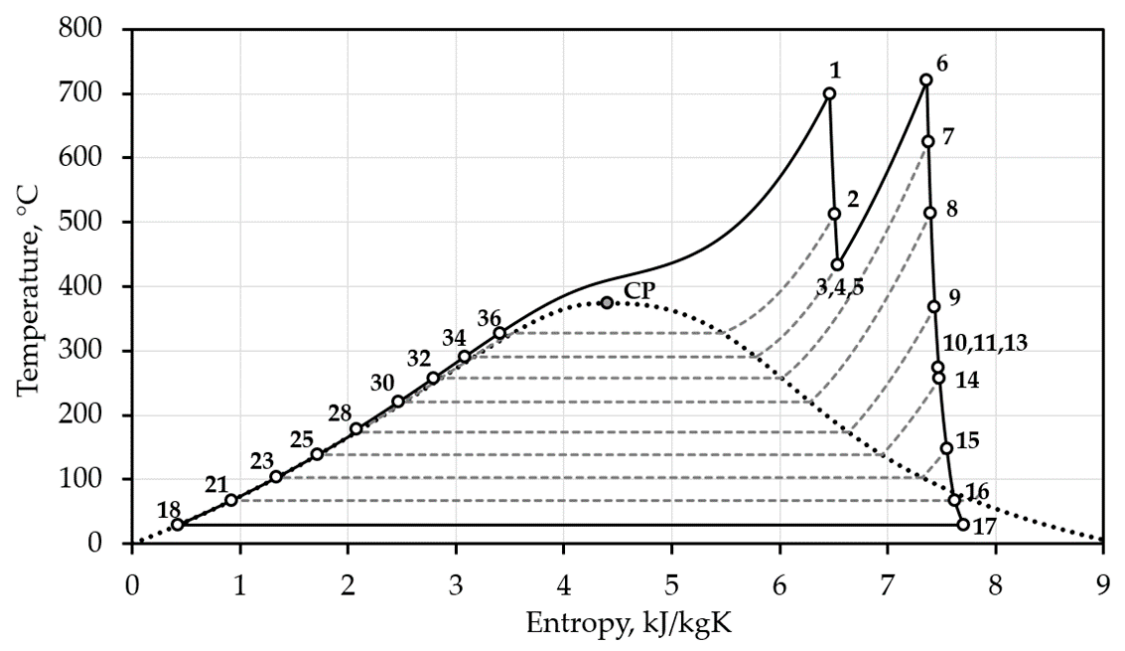

Figure 3. Temperature-entropy chart of the reference advanced ultra-supercritical (A-USC) steam cycle with. superheat/reheat temperatures of $700 / 720^{\circ} \mathrm{C}$ and pressures of $350 / 75$ bar.

Table 5. Reference A-USC steam cycle: $\dot{m}-T-p$ data.

\begin{tabular}{cccccccc}
\hline Point & $\dot{\boldsymbol{m}} \mathbf{( k g} / \mathbf{s})$ & $\mathbf{T}\left({ }^{\circ} \mathbf{C}\right)$ & $\boldsymbol{p}$ (Bar) & Point & $\dot{\boldsymbol{m}} \mathbf{( \mathbf { k g } / \mathbf { s } )}$ & $\boldsymbol{T}\left({ }^{\circ} \mathbf{C}\right)$ & $\boldsymbol{p}(\mathbf{B a r})$ \\
\hline $\mathbf{1}$ & 493.40 & 700.00 & 350.00 & $\mathbf{2 1}$ & 348.89 & 65.07 & 19.00 \\
$\mathbf{2}$ & 41.45 & 517.30 & 128.44 & $\mathbf{2 2}$ & 40.29 & 70.07 & 1.12 \\
$\mathbf{3}$ & 451.96 & 443.33 & 80.00 & $\mathbf{2 3}$ & 348.89 & 100.81 & 18.00 \\
$\mathbf{4}$ & 34.99 & 443.33 & 80.00 & $\mathbf{2 4}$ & 20.51 & 105.81 & 3.43 \\
$\mathbf{5}$ & 416.95 & 443.33 & 80.00 & $\mathbf{2 5}$ & 348.89 & 136.19 & 17.00 \\
$\mathbf{6}$ & 416.95 & 720.00 & 75.00 & $\mathbf{2 6}$ & 348.89 & 136.19 & 17.00 \\
$\mathbf{7}$ & 24.50 & 630.61 & 46.46 & $\mathbf{2 7}$ & 493.40 & 173.43 & 8.60 \\
$\mathbf{8}$ & 23.56 & 519.26 & 24.11 & $\mathbf{2 8}$ & 493.40 & 180.08 & 404.00 \\
$\mathbf{9}$ & 20.00 & 372.47 & 8.87 & $\mathbf{2 9}$ & 124.51 & 185.08 & 23.39 \\
$\mathbf{1 0}$ & 348.89 & 274.28 & 4.00 & $\mathbf{3 0}$ & 493.40 & 218.44 & 403.00 \\
$\mathbf{1 1}$ & 37.93 & 274.11 & 3.88 & $\mathbf{3 1}$ & 100.95 & 223.44 & 45.06 \\
$\mathbf{1 2}$ & - & - & - & $\mathbf{3 2}$ & 493.40 & 255.52 & 402.00 \\
$\mathbf{1 3}$ & 310.96 & 274.11 & 3.88 & $\mathbf{3 3}$ & 76.45 & 260.52 & 77.60 \\
$\mathbf{1 4}$ & 20.51 & 263.74 & 3.54 & $\mathbf{3 4}$ & 493.40 & 290.89 & 401.00 \\
$\mathbf{1 5}$ & 19.78 & 152.82 & 1.15 & $\mathbf{3 5}$ & 41.45 & 295.89 & 124.59 \\
$\mathbf{1 6}$ & 19.00 & $x=0.975$ & 0.28 & $\mathbf{3 6}$ & 493.40 & 325.56 & 400.00 \\
$\mathbf{1 7}$ & 251.67 & $x=0.913$ & 0.04 & $\mathbf{3 7}$ & 37.93 & $x=0.913$ & 0.04 \\
$\mathbf{1 8}$ & 348.89 & 29.00 & 0.04 & $\mathbf{3 8}$ & - & - & - \\
$\mathbf{1 9}$ & 348.89 & 29.16 & 20.00 & $\mathbf{3 9}$ & 19235.23 & 17.00 & 4.50 \\
$\mathbf{2 0}$ & 59.29 & 34.16 & 0.27 & $\mathbf{4 0}$ & 19235.23 & 25.00 & 2.00 \\
\hline
\end{tabular}

Table 6. Results for the reference steam cycles.

\begin{tabular}{|c|c|c|c|c|}
\hline Power Plant Type & SUBC & SC & USC & A-USC \\
\hline Fuel heat input, $\mathrm{MW}_{\mathrm{th}}$ & 1760.1 & 1627.2 & 1544.8 & 1469.5 \\
\hline Live steam mass flow rate, $\mathrm{kg} / \mathrm{s}$ & 625.2 & 592.7 & 563.7 & 493.0 \\
\hline Flue gases mass flow rate, $\mathrm{kg} / \mathrm{s}$ & 762.6 & 705.1 & 669.4 & 636.7 \\
\hline $\mathrm{CO}_{2}$ emissions, $\mathrm{kg} / \mathrm{s}$ & 161.8 & 149.6 & 142.1 & 135.1 \\
\hline $\mathrm{CO}_{2}$ emissions, $\mathrm{kg} / \mathrm{MWh}_{\mathrm{el}}$ & 832.3 & 769.5 & 730.5 & 694.9 \\
\hline Condenser thermal discharge, $\mathrm{MW}_{\mathrm{th}}$ & 905.0 & 786.6 & 714.6 & 643.1 \\
\hline Gross electric power, $\mathrm{MW}_{\mathrm{el}}$ & 735 & 735 & 735 & 735 \\
\hline Net electric power, $\mathrm{MW}_{\mathrm{el}}$ & 700 & 700 & 700 & 700 \\
\hline Gross thermal efficiency, \% & 41.76 & 45.17 & 47.58 & 50.02 \\
\hline Net thermal efficiency, \% & 39.77 & 43.02 & 45.31 & 47.64 \\
\hline
\end{tabular}




\subsection{The CCS Integrated Steam Cycle}

Even though the volume fraction of $\mathrm{CO}_{2}$ in flue gases is only $14.4 \%$, post-combustion capture can be successfully applied to remove the majority of it. Table 7 reports the most relevant results in the four CCS integrated steam cycles. The fuel heat input, the live steam, and flue gases mass flow rates are unaffected by the CCS and can be read from Table 6 . The results in Table 7 are obtained using baseline CCS duties of $3.5 \mathrm{MJ}$ th $/ \mathrm{kg}_{\mathrm{CO} 2}$ for heating (30 $\mathrm{wt} \%$ MEA solution), $4.6 \mathrm{MJ}$ th $/ \mathrm{kg}_{\mathrm{CO} 2}$ for cooling, $0.35 \mathrm{MJ} / \mathrm{kg}_{\mathrm{CO} 2}$ for an eight-stage $\mathrm{CO}_{2}$ compression with seven intercoolers, and an additional $0.15 \mathrm{MJ} \mathrm{el}_{\mathrm{el}} / \mathrm{kg}_{\mathrm{CO} 2}$ for auxiliary power consumption for $\mathrm{CO}_{2}$ capture, solvent pumps, and cooling water pumps. Basic heat integration is taken into account while advanced heat integration is disregarded.

Table 7. Results for the CCS integrated steam cycles.

\begin{tabular}{|c|c|c|c|c|}
\hline Power Plant Type & SUBC & SC & USC & A-USC \\
\hline CCS steam extraction, $\mathrm{kg} / \mathrm{s}$ & 203.7 & 195.6 & 191.3 & 175.1 \\
\hline CCS heating load, $\mathrm{MW}_{\mathrm{th}}$ & 509.8 & 471.3 & 447.5 & 425.6 \\
\hline CCS cooling load, $\mathrm{MW}_{\mathrm{th}}$ & 668.5 & 618.0 & 586.8 & 558.2 \\
\hline CCS auxiliary power, $\mathrm{MW}_{\mathrm{el}}$ & 68.6 & 65.3 & 63.9 & 60.8 \\
\hline Captured $\mathrm{CO}_{2}, \mathrm{~kg} / \mathrm{s}$ & 145.6 & 134.6 & 127.9 & 121.6 \\
\hline $\mathrm{CO}_{2}$ emissions, $\mathrm{kg} / \mathrm{s}$ & 16.2 & 15.0 & 14.2 & 13.5 \\
\hline $\mathrm{CO}_{2}$ emissions, $\mathrm{kg} / \mathrm{MWh}_{\mathrm{el}}$ & 83.2 & 77.0 & 73.1 & 69.5 \\
\hline Gross electric power, $\mathrm{MW}_{\mathrm{el}}$ & 595.5 & 626.9 & 634.2 & 637.2 \\
\hline Net electric power, $\mathrm{MW}_{\mathrm{el}}$ & 491.9 & 526.6 & 535.4 & 541.4 \\
\hline Power loss factor $\sigma,-$ & 0.290 & 0.236 & 0.225 & 0.230 \\
\hline Overall EOP, $\mathrm{kWh}$ el $/ \mathrm{t}_{\mathrm{CO} 2}$ & 397.0 & 357.9 & 357.7 & 362.3 \\
\hline Gross thermal efficiency, \% & 33.83 & 38.53 & 41.06 & 43.36 \\
\hline Net thermal efficiency, \% & 27.95 & 32.36 & 34.66 & 36.84 \\
\hline Net efficiency loss, \%-pts. & 11.82 & 10.66 & 10.65 & 10.80 \\
\hline
\end{tabular}

Overall, the power plant performance is largely affected by the CCS unit. The net efficiency losses are 11.82, 10.66, 10.65, and 10.80\%-pts in the respective SUBC, SC, USC, and A-USC power plants, as shown in Figure 4. The power loss factor (7) arising from IP/LP steam extraction suggests that between $22.5 \%$ and $29.0 \%$ of the steam heat flow is converted into lost electricity generation. The highest overall electricity output penalty (EOP) is seen in the SUBC power plant $\left(397.0 \mathrm{kWh} / \mathrm{t}_{\mathrm{CO} 2}\right)$, mainly because of the higher steam pressure in the IP/LP crossover extraction. The lowest EOPs are achieved in the SC and USC steam cycles ( 357.9 and $357.7 \mathrm{kWh} / \mathrm{t}_{\mathrm{CO} 2}$ ) while the A-USC has a slightly larger EOP $\left(362.3 \mathrm{kWh} / \mathrm{t}_{\mathrm{CO} 2}\right)$. This can be explained by the reduced fuel consumption in the A-USC and the relative increase in the ratio between net electricity loss and captured $\mathrm{CO}_{2}$ rate (13). The reduced fuel consumption in the A-USC causes a reduced mass flow rate of captured $\mathrm{CO}_{2}$ along with lower auxiliary power consumption for $\mathrm{CO}_{2}$ compression. Consequently, the highest net electric power is obtained in the A-USC CCS steam cycle.

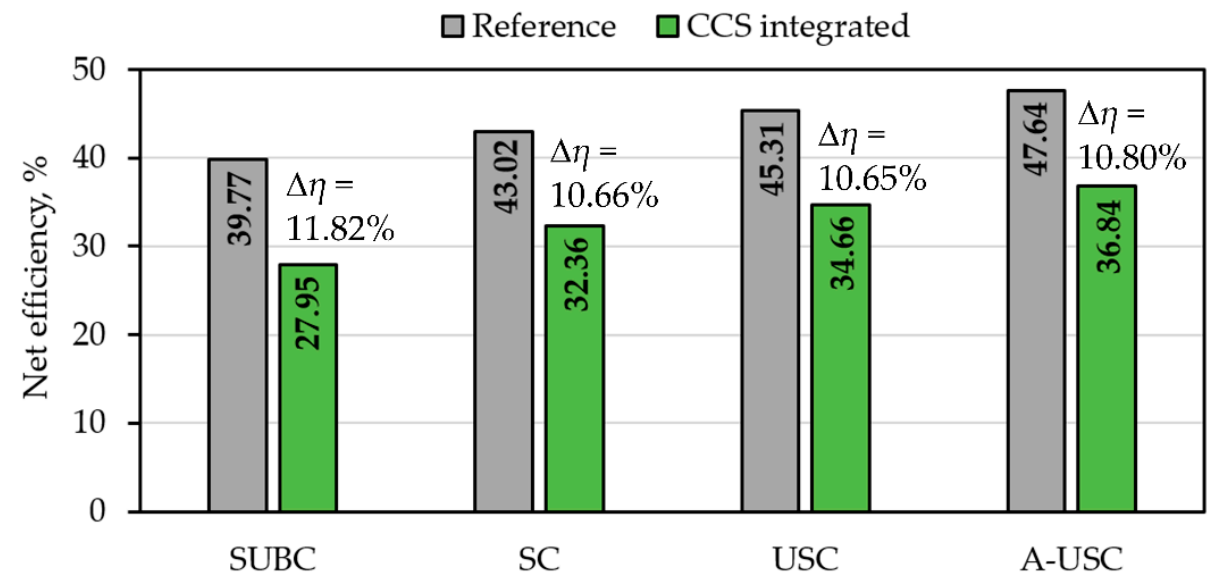

Figure 4. Reference and CCS integrated power plants net efficiencies. 
The assumed $\mathrm{CO}_{2}$ removal rate of $90 \%$ yields specific $\mathrm{CO}_{2}$ emissions between 69.5 and $83.2 \mathrm{~kg} / \mathrm{MWh}_{\mathrm{el}}$ in the respective A-USC and SUBC steam cycles. It should be noted that these numbers represent direct $\mathrm{CO}_{2}$ emissions from coal combustion in CCS coal plants. Indirect $\mathrm{CO}_{2}$ emissions, arising from coal mining and transport as well as from the power plant construction and operation, can contribute $30 \%$ or more in total emissions [43]. Lifecycle $\mathrm{CO}_{2}$ emissions for coal CCS power plants, including direct and indirect sources, are estimated between 103 and $129 \mathrm{kgCO}_{2} / \mathrm{MWh}_{\mathrm{el}}[44]$.

\subsection{Factors Affecting the Electricity Penalty \\ 3.4.1. Reboiler Heating Duty}

The dominant factor affecting the electricity penalty is the reboiler heating duty for absorbent regeneration. Amine absorbents such as monoethanolamine (MEA) and methyldiethanolamine (MDEA) are considered mature technologies, commercially available for scrubbing of dilute $\mathrm{CO}_{2}$ from flue gases. MEA has high $\mathrm{CO}_{2}$ absorption rates but at the expense of large heating duties (3.1-4.2 $\left.\mathrm{MJ}_{\mathrm{th}} / \mathrm{kg}_{\mathrm{CO} 2}\right)$, caused by high enthalpies of reaction with $\mathrm{CO}_{2}$. MDEA solutions offer lower heating demands but at the drawback of reduced $\mathrm{CO}_{2}$ absorption rates. Amine solutions blended with $\mathrm{CO}_{2}$ absorption promoters [45] and non-amine absorbents are being studied to alleviate the electricity penalty in CCS integrated power plants. Aqueous ammonia $\left(\mathrm{NH}_{3}\right)$, aqueous piperazine (PZ), potassium carbonate $\left(\mathrm{K}_{2} \mathrm{CO}_{3}\right)$, and mixed-salt technology (MST) are potential alternatives with heat requirements as low as $2.0 \mathrm{MJ}_{\mathrm{th}} / \mathrm{kgCO}_{2}$ [46] that could be deployed for large-scale CCS in the future.

Figure 5 shows the net efficiency loss and the electricity output penalty (EOP) in the A-USC steam cycle with respect to the specific heating duty, the reboiler temperature, and for different absorbent solutions. The reboiler heating duty determines the steam quantity while the reboiler temperature defines the steam quality to be extracted from the IP/LP crossover pipe [38]. The reboiler temperature dictates the steam condensation pressure in the reboiler and the pressure of the steam extraction from the IP/LP crossover. Generally, it can be seen that the net efficiency penalty increases with the reboiler heating duty and the reboiler temperature, which, on the other hand, depend on the absorbent type and process optimizations.

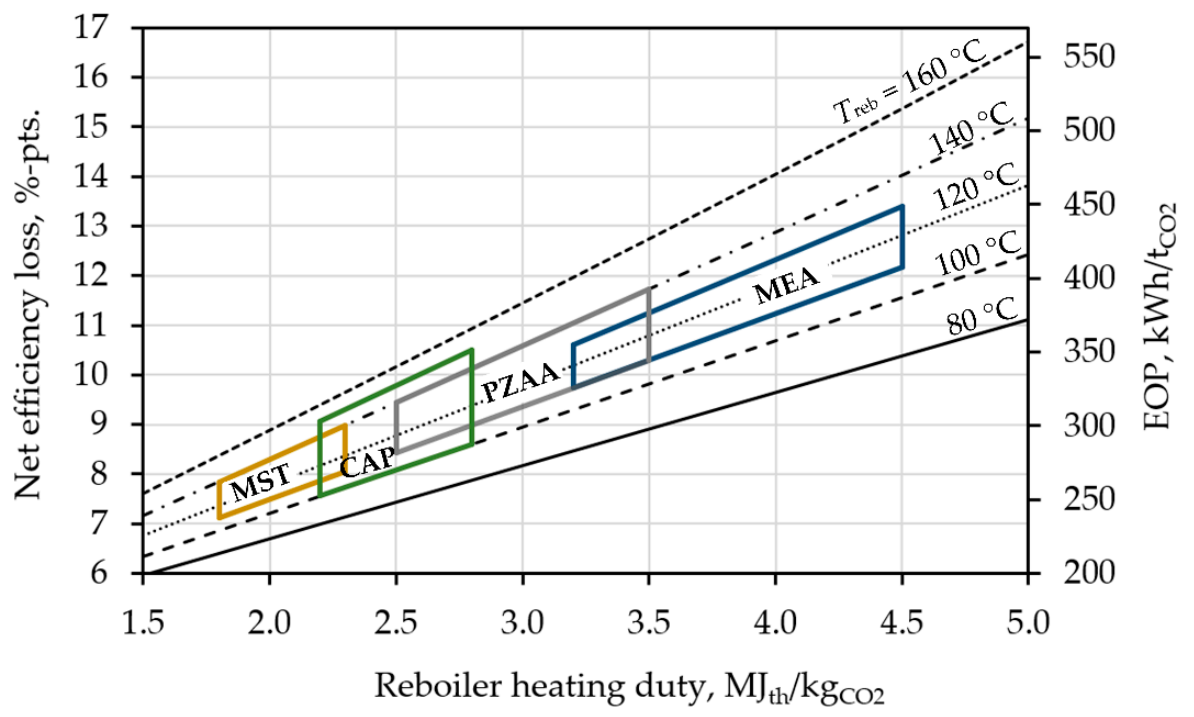

Figure 5. Net efficiency loss and electricity output penalty against reboiler heating duty and temperature for the A-USC power plant.

The reference $30 \mathrm{wt} \%$ MEA absorbent has a specific heating duty in the range between 3.2-4.5 $\mathrm{MJ}_{\mathrm{th}} / \mathrm{kg}_{\mathrm{CO} 2}$ at reboiler temperature of $110-130{ }^{\circ} \mathrm{C}$ [38]. The resulting net efficiency loss is between 9.73 and $13.40 \%$-pts and EOPs between 326.6 and $449.8 \mathrm{kWh} / \mathrm{t}_{\mathrm{CO}}$. Piperazine 
activated absorbents (PZAA) offer higher $\mathrm{CO}_{2}$ absorption rates than MEA, with heating demands between $2.5-3.5 \mathrm{MJ}_{\mathrm{th}} / \mathrm{kg}_{\mathrm{CO} 2}$ and reboiler temperatures of $110-140{ }^{\circ} \mathrm{C}[45,47,48]$. This leads to reduced net efficiency losses, between 8.42 and $11.72 \%$-pts, and EOPs between 282.6 and $393.4 \mathrm{kWh} / \mathrm{t}_{\mathrm{CO} 2}$. Chilled ammonia process (CAP) operates with duties between 2.2 and $2.8 \mathrm{MJ}_{\mathrm{th}} / \mathrm{kgCO}$ [49] and reboiler temperatures of $100-150{ }^{\circ} \mathrm{C}$ [50], resulting in efficiency losses between 7.55 and $10.51 \%$-pts and EOPs in the range of $253.4-352.8 \mathrm{kWh} / \mathrm{t}_{\mathrm{CO} 2}$. Further reduction in the net efficiency loss is possible with absorbent having even lower reboiler duties. For example, mixed-salt technology (MST) at demonstration scale achieves reboiler heating duties of $1.8-2.5 \mathrm{MJ}_{\mathrm{th}} / \mathrm{kg}_{\mathrm{CO} 2}$ with reboiler temperatures of $110-140{ }^{\circ} \mathrm{C}$. The net efficiency loss from MST absorption process would then be between 7.84 and $8.98 \%$-pts and EOPs between 263.2 and $301.4 \mathrm{kWh} / \mathrm{t}_{\mathrm{CO} 2}$. MST offers additional gains in the compression power since $\mathrm{CO}_{2}$ pressures of 2-10 bar are attainable at the stripper outlet [46]. Overall, the reboiler heating duty is a huge burden to electricity generation in the CCS integrated A-USC coal-fired power plant. Even the lowest of heating duties, $2.0 \mathrm{MJ}$ th $/ \mathrm{kgCO}_{\mathrm{C}}$, causes efficiency losses of around $8 \%$-pts and EOPs of $270 \mathrm{kWh} / \mathrm{t}_{\mathrm{CO}}$. On the other hand, these penalties come along with the benefit of large $\mathrm{CO}_{2}$ emission reductions.

\subsubsection{Compression Power Duty}

The $\mathrm{CO}_{2}$ compression power duty is the second most-important factor determining the electricity penalty of the CCS integrated power plant. All the results so far were obtained for a baseline $\mathrm{CO}_{2}$ compression scenario including eight-stage compression, constant pressure ratio and efficiency of 0.80 in all compressors, a total pressure rise from 1 bar at the inlet to 150 bar at the outlet, seven intercoolers with a pressure drop of 0.2 bar each, and cooling $\mathrm{CO}_{2}$ down to $30{ }^{\circ} \mathrm{C}$ between stages. The following analysis is carried out assuming the baseline CCS heating duty of $3.5 \mathrm{MJ} \mathrm{th}_{\mathrm{th}} / \mathrm{kgCO}_{\mathrm{CO}}(30 \mathrm{wt} \% \mathrm{MEA})$ and an additional auxiliary power of $0.15 \mathrm{MJ} \mathrm{el} / \mathrm{kgCO}_{2}$, compression excluded.

The baseline $\mathrm{CO}_{2}$ compression, shown in Figure $6 \mathrm{a}$, returns a specific auxiliary consumption of $0.345 \mathrm{MJ}_{\mathrm{el}} / \mathrm{kgCO}_{\mathrm{C}}$, whereas the theoretical minimum (isothermal compression) is $0.296 \mathrm{MJ}_{\mathrm{el}} / \mathrm{kgCO}_{\mathrm{C}}$. By selecting fewer intermediate cooling stages, the compression duty increases since the compression process departs from an optimum isothermal compression. For example, the same eight-stage compression process with three intercooling stages would need $0.386 \mathrm{MJ}_{\mathrm{el}} / \mathrm{kgCO}_{\mathrm{C}}$, an increase of $12 \%$ with respect to the baseline case, as shown in Figure 6b.
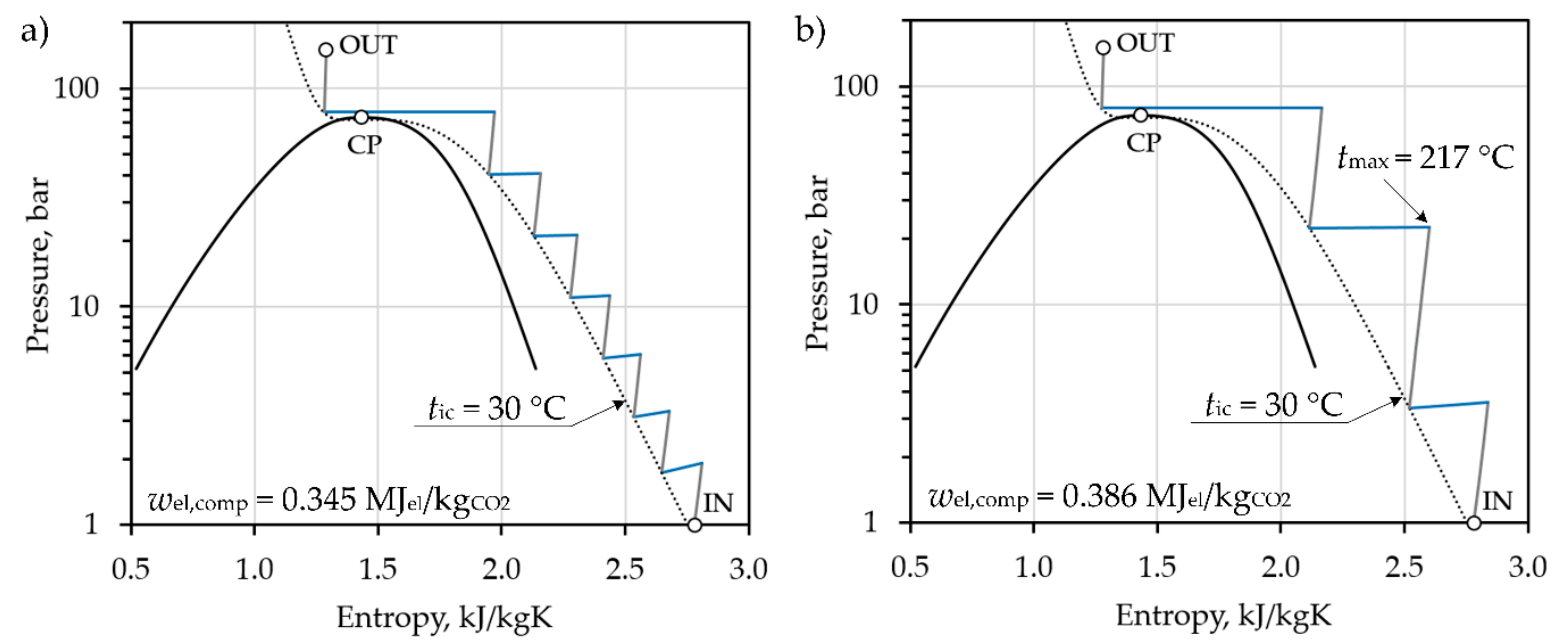

Figure 6. Pressure-entropy chart for the eight-stage $\mathrm{CO}_{2}$ compression with: (a) Seven intercooling stages (b) three intercooling stages.

The impact of the number of intercooling stages as well as the effect of the $\mathrm{CO}_{2}$ inlet pressure on the compression power consumption is shown in Figure 7. For an eight-stage 
compression process, three or less intercooling return with prohibitively high efficiency losses and excessive $\mathrm{CO}_{2}$ discharge temperatures $\left(217^{\circ} \mathrm{C}\right.$, Figure $\left.6 \mathrm{~b}\right)$. At four intercooling stages the maximum discharge temperature is $160^{\circ} \mathrm{C}$ and, relatively to the baseline case with seven intercoolers, the net efficiency losses are $0.18,0.17,0.16$, and $0.14 \%$-pts for inlet pressures of 1, 2, 5, and 10 bar, respectively. Additional intercooling stages bring less and less efficiency gains, whereas the difference between six and seven stages is less than $0.05 \%$-pts for all inlet pressures. The $\mathrm{CO}_{2}$ inlet pressure depends on the solution conditions in the desorber. Generally, $\mathrm{CO}_{2}$ inlet pressures between 1 and 2 bar are attainable with MEA solutions. Just a small increment in the inlet pressure shows substantial benefits, a reduction of $18 \%$ in the compression power duty is achieved between inlet pressures of 1 bar and 2 bar. This converts into a net efficiency gain of around $0.50 \%$-pts for four to seven intercooling stages. The efficiency gains decrease for higher inlet pressures, the efficiency gain is $1.20 \%$-pts between 1 bar and 5 bar, and $1.70 \%$-pts between 1 bar and 10 bar. This is expected since compression power duty contributes with $28 \%$ in the total efficiency loss of the CCS integrated A-USC power plant.

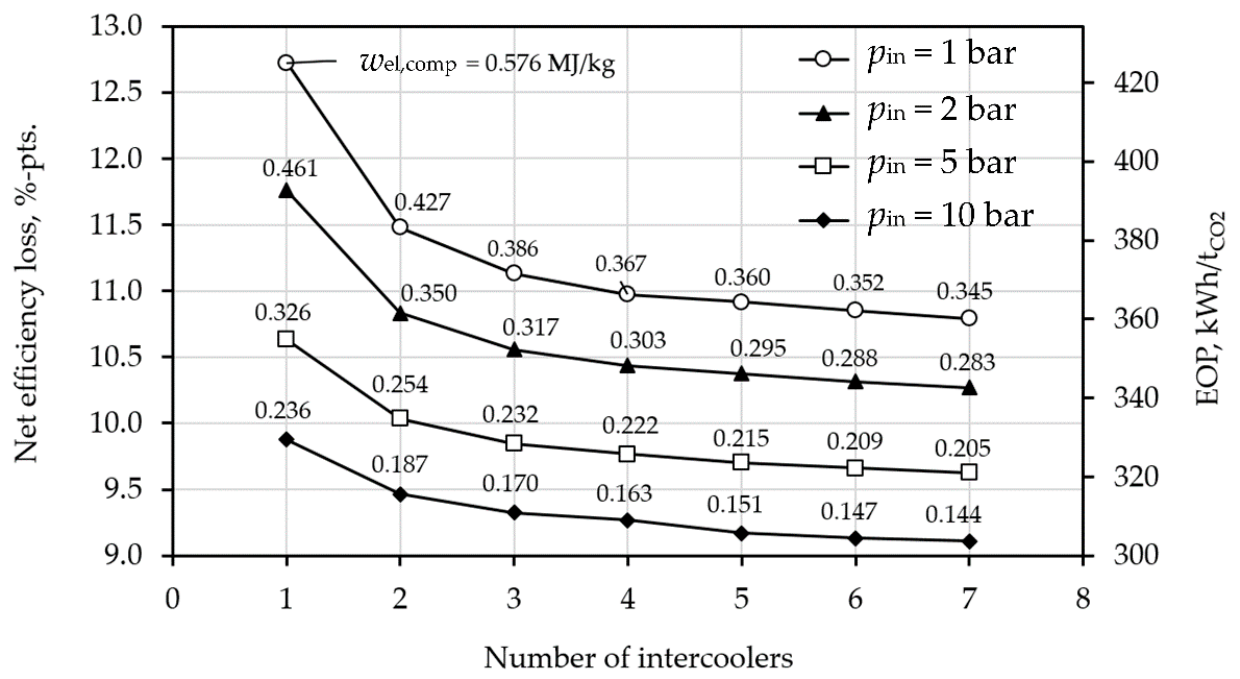

Figure 7. Net efficiency loss, electricity output penalty (EOP) and compression power duty as function of the number of intercooling stages and $\mathrm{CO}_{2}$ inlet pressure.

\subsubsection{Advanced Heat Integration}

Advanced heat integration (AHI) can be used to further reduce the CCS penalty. This includes preheating the LP condensate using low-temperature waste heat from $\mathrm{CO}_{2}$ intercoolers and from the desorber overhead condenser. The amount of waste heat that can be integrated in the LP feedwater preheating line depends on the quantity (CCS heating duty) and quality (reboiler temperature) of waste heat as well as on the feedwater temperatures in the LP preheating line. The amount of integrable waste heat is limited by the maximum temperature in the LP preheating line. Assuming that the HP and IP steam extractions are unaffected by the CCS unit, this maximum temperature would be the temperature at the feedwater tank inlet $\left(136.2^{\circ} \mathrm{C}\right.$, point (26) in Table 5.).

The net efficiency gain and the electricity output gain (EOG) in the analyzed CCS A-USC steam cycle is shown in Figure 8 against the reboiler heating duty and the reboiler temperature. It can be seen that AHI offers higher efficiency gains at low reboiler heating duties and high reboiler temperatures. For a given reboiler temperature, the net efficiency gain increases by reducing the reboiler heating duty. In addition, for a given reboiler heating duty, the net efficiency gain increases with the reboiler temperature, but with some exceptions. When the waste heat temperature and the waste heat quantity are such that the feedwater tank inlet temperature is reached, additional waste heat cannot be allocated into the LP feedwater preheating line. This means that the entire LP feedwater preheating range is supplied by waste heat, the LP FWHs are bypassed, and the LP steam 
extractions are closed. From this point onwards, the AHI efficiency gain drops abruptly since steam is extracted from the IP/LP crossover, but waste heat is not returned into the LP preheating line. As shown in Figure 8, the maximum LP feedwater temperature is achieved for: (1) Reboiler temperature of $140{ }^{\circ} \mathrm{C}$ and specific heating duty of $4.14 \mathrm{MJ}_{\mathrm{th}} / \mathrm{kg}_{\mathrm{CO} 2}$ and (2) for reboiler temperature of $160{ }^{\circ} \mathrm{C}$ and specific heating duty of $2.69 \mathrm{MJ}_{\mathrm{th}} / \mathrm{kgCO}_{\mathrm{CO}}$. AHI applied on the A-USC steam cycle configuration bring an efficiency gain of $0.53 \%$-pts for $\mathrm{CO}_{2}$ absorption with $30 \mathrm{wt} \%$ MEA solution $\left(3.50 \mathrm{MJ}\right.$ th $\left./ \mathrm{kg}_{\mathrm{CO} 2}, 120{ }^{\circ} \mathrm{C}\right)$. In that case, the corresponding electricity output gain is $17.8 \mathrm{kWh} / \mathrm{t}_{\mathrm{CO} 2}$.

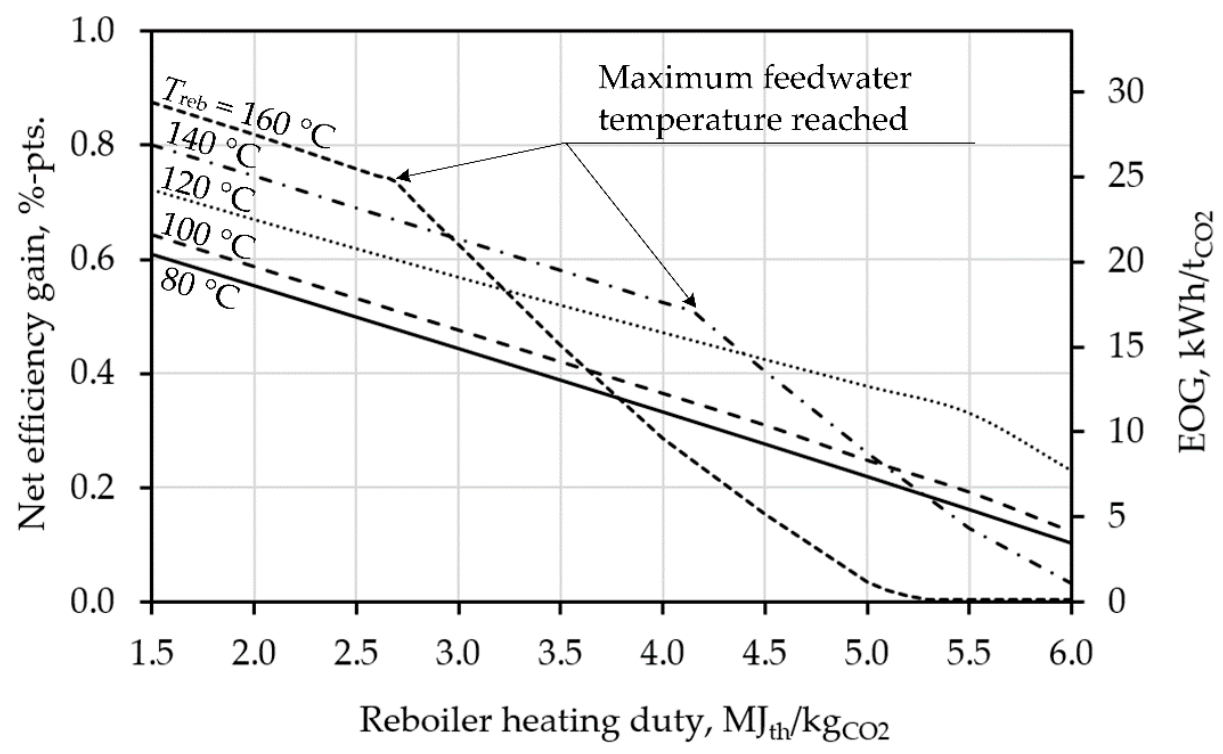

Figure 8. Net efficiency gain and electricity output gain (EOG) from advanced heat integration.

\subsection{Future Outlook}

The levels of contributing factors in the net efficiency loss and electricity output penalty of the A-USC power plant are shown in Figure 9. Present state levels are calculated for a specific heating duty of $3.5 \mathrm{MJ}$ th $/ \mathrm{kgCO}_{2}$, a cooling duty of $4.6 \mathrm{MJ}_{\mathrm{th}} / \mathrm{kgCO}_{2}$, a compression duty of $0.35 \mathrm{MJ}_{\mathrm{el}} / \mathrm{kgCO}_{2}$, and an auxiliary duty of $0.15 \mathrm{MJ} \mathrm{el} / \mathrm{kgCO}_{2}$. The resulting net efficiency loss is $10.80 \%$-pts and the EOP is $362.3 \mathrm{kWh}$ el $/ \mathrm{tCO}_{2}$. Steam extraction is found to contribute with $6.7 \%$-pts, $\mathrm{CO}_{2}$ compression power contributes with $2.8 \%$-pts, and CCS auxiliary power adds $1.3 \%$-pts to the total efficiency loss.

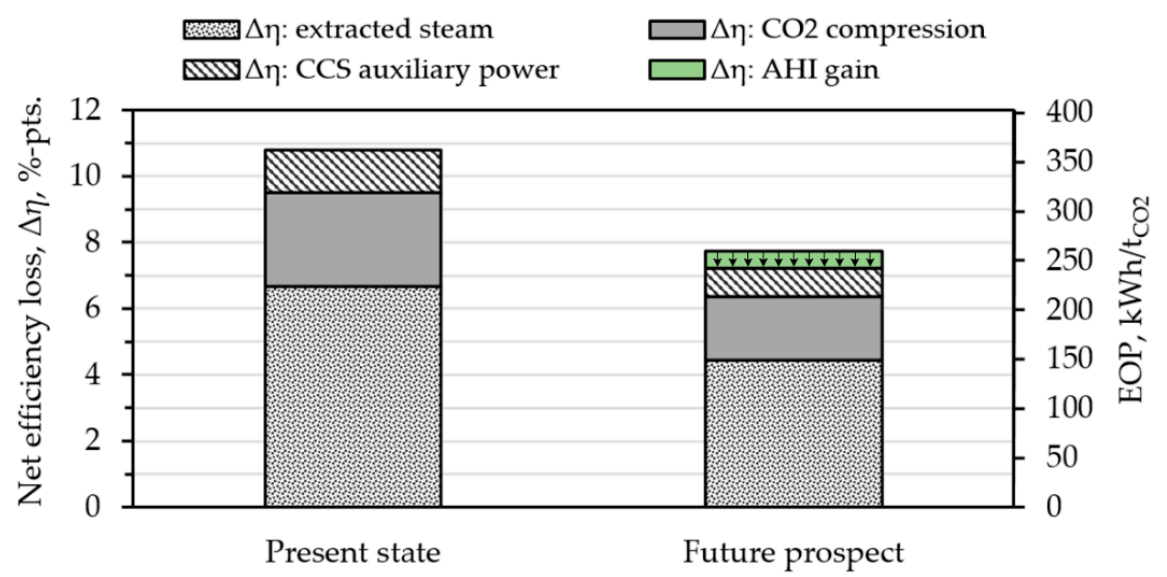

Figure 9. Present state and future prospect on the net efficiency loss and electricity penalty for CCS integrated A-USC units. 
The levels for future prospect are obtained assuming an average $30 \%$ reduction in CCS energy requirements relative to present day technology. The reduced heating and cooling energy duties of $2.5 \mathrm{MJ}_{\mathrm{th}} / \mathrm{kgCO}_{2}$ and $3.4 \mathrm{MJ}_{\mathrm{th}} / \mathrm{kgCO}_{2}$ could be achieved with enhanced $\mathrm{CO}_{2}$ absorbents, $\mathrm{CCS}$ process optimization, and advanced heat integration (AHI). The reduced power duties of $0.25 \mathrm{MJ}_{\mathrm{el}} / \mathrm{kgCO}_{2}$ for compression and $0.11 \mathrm{MJ}_{\mathrm{el}} / \mathrm{kgCO} \mathrm{K}_{2}$ for auxiliaries could be achieved with higher $\mathrm{CO}_{2}$ inlet pressures ( 3 bar) and highly efficient compressors. The net efficiency loss of future CCS is estimated at $7.20 \%$-pts, an improvement of 3.6\%-pts over present day available technology. The EOP would be reduced to $241.7 \mathrm{kWh}_{\mathrm{el}} / / \mathrm{t}_{\mathrm{CO} 2}$, down by one-third relatively to the present EOP.

All this suggests that future planned CCS integrated A-USC power plants could operate above $40 \%$ net efficiency with direct $\mathrm{CO}_{2}$ emissions as low as $70 \mathrm{~kg} / \mathrm{MWh}$, whereas the same units without CCS are expected to achieve $47.6 \%$ net efficiency but 10 times the amount of $\mathrm{CO}_{2}$ emissions. Present-day fossil fuel power plants without CCS are marked by high $\mathrm{CO}_{2}$ emission per unit of generated electricity: Between 877 and $1130 \mathrm{kgCO}_{2} / \mathrm{MWh}_{\mathrm{el}}$ for coal and between 422 and $548 \mathrm{kgCO}_{2} / \mathrm{MWh}_{\mathrm{el}}$ for natural gas. On the other hand, coal CCS would achieve $\mathrm{CO}_{2}$ emissions in the range between 103 and $129 \mathrm{~kg} / \mathrm{MWh}$, including direct and indirect emissions [44]. Natural gas CCGT power plants would achieve even lower $\mathrm{CO}_{2}$ emissions than coal, between 69 and $84 \mathrm{~kg} / \mathrm{MWh}$ as reported in [44]. However, carbon emissions from coal CCS and natural gas CCS power plants would still be higher than $\mathrm{CO}_{2}$ emissions from renewable energy sources. Large hydropower and nuclear power generate electricity with $\mathrm{CO}_{2}$ emissions of 3-7 kg/MWh and 8-45 kg/MWh, respectively [51]. Solar PV and solar CSP generate electricity with emissions in the range between 29 and $80 \mathrm{~kg} / \mathrm{MWhel}$, and between 14 and $32 \mathrm{~kg} / \mathrm{MWh}$, respectively. Wind power generates electricity with lifecycle $\mathrm{CO}_{2}$ emission between 8 and $20 \mathrm{~kg} / \mathrm{MWh}$ while geothermal energy has emission levels between 20 and $57 \mathrm{~kg} / \mathrm{MWh}$ [51].

\section{Conclusions}

Advanced ultra-supercritical coal-fired power plants are expected to enter operation in the next decade. These steam cycles will use advanced steel alloys and highly efficient steam generators and turbines to generate electricity from steam conditions in excess of $700{ }^{\circ} \mathrm{C}$ and 350 bar. The estimated thermal efficiency of future planned A-USC units is $50 \%$ gross and $47.6 \%$ net. Relatively to subcritical units, the net efficiency of A-USC is $8 \%$-pts higher while $\mathrm{CO}_{2}$ emissions are $16.5 \%$ lower. However, $\mathrm{CO}_{2}$ emissions per unit of generated electricity would still be around $700 \mathrm{kgCO}_{2} / \mathrm{MWh}_{\mathrm{el}}$.

Post-combustion $\mathrm{CO}_{2}$ capture and storage can be successfully integrated into AUSC power plants to reduce $\mathrm{CO}_{2}$ emissions by $90 \%$ or more, down to $70 \mathrm{~kg} \mathrm{CO}_{2} / \mathrm{MWh}_{\mathrm{el}}$. However, the power plant performance and electricity output are largely affected by the energy requirements in CCS units. The present study analyzed the interface factors between the CCS unit the power plant affecting the A-USC steam cycle efficiency. Calculations have shown that $\mathrm{CO}_{2}$ absorption by $30 \mathrm{wt} \%$ MEA solution result with net efficiency losses in the range between 9.7 and $13.4 \%$-pts depending on the reboiler heating duty and temperature. MEA based blends, piperazine activated absorbents, chilled ammonia, and mixed salts could be used instead to reduce the efficiency losses down 7.8-11.7\%-pts.

The influence of number of intercooling stages and $\mathrm{CO}_{2}$ inlet pressures were analyzed next. For an eight-stage compression process, seven intercooling stages reduce the net efficiency loss by $0.14-0.18 \%$-pts relatively to four stages. The $\mathrm{CO}_{2}$ pressure at the compression inlet has an even stronger influence. Between inlet pressures of 1 and 2 bar there is a net efficiency gain of $0.5 \%$-pts while between inlet pressures of 1 and 5 bar the net efficiency gain is $1.2 \%$-pts.

Advanced heat integration by recycling of low-temperature waste heat from the CCS unit is found to bring an additional efficiency gain of $0.4-0.6 \%$ pts to the steam cycle.

Present day CCS technology causes a net efficiency loss of $10.8 \%$-pts and an electricity output penalty of $362.3 \mathrm{kWh}$ el $/ \mathrm{tCO}_{2}$ in the A-USC baseline scenario. Future CCS technology is expected to develop into the direction of reduced energy demand and improved $\mathrm{CO}_{2}$ 
absorption rates. Enhanced $\mathrm{CO}_{2}$ absorbents, improved compression strategies, and advanced heat integration could reduce the net efficiency loss and the electricity output penalty down to $7.2 \%$-pts and $241.7 \mathrm{kWh}$ el $/ \mathrm{t}_{\mathrm{CO} 2}$, a 30\% improvement over existing CCS technology.

From a technical perspective, post-combustion CCS is ready for integration into the fossil fuel electric power industry. However, the electricity penalties and the financial downsides caused by CCS are the principal reasons dissuading electric utilities from implementing CCS at large-scale. Legal and financial aspects concerning CCS and the carbon emission trading systems need further upgrades to pave the way towards the power industry decarbonization, for which CCS emerges as the solution.

Author Contributions: Conceptualization, B.T. and P.B.; methodology, B.T. and P.B.; software, P.B.; validation, P.B., I.B., and V.G.; formal analysis, B.T. and P.B.; investigation, P.B. and I.B.; resources, V.G.; data curation, P.B. and V.G.; writing—original draft preparation, B.T. and P.B.; writing-review and editing, I.B. and V.G.; visualization, P.B.; supervision, I.B. and V.G. All authors have read and agreed to the published version of the manuscript.

Funding: This research received no external funding.

Institutional Review Board Statement: Not applicable.

Informed Consent Statement: Not applicable.

Data Availability Statement: Not applicable.

Conflicts of Interest: The authors declare no conflict of interest.

\section{References}

1. BP Statistical Review of World Energy 2020, 69th ed. 2020. Available online: https://www.bp.com/content/dam/bp/businesssites/en/global/corporate/pdfs/energy-economics/statistical-review/bp-stats-review-2020-full-report.pdf (accessed on 1 November 2020).

2. IEA World Energy Outlook 2020. 2020. Available online: https:/ /www.iea.org/reports/world-energy-outlook-2020/achievingnet-zero-emissions-by-2050\#abstract (accessed on 1 November 2020).

3. Jayarama Reddy, P. Clean Coal Technologies for Power Generation; CRC Press: Boca Raton, FL, USA; Taylor \& Francis Group: London, UK, 2014.

4. Nomoto, H. Advanced ultra-supercritical pressure steam turbines and their combination with carbon capture and storage systems (CCS). In Advances in Steam Turbines for Modern Power Plants; Tanuma, T., Ed.; Woodhead Publishing: Cambridge, UK, 2017; pp. 501-519.

5. Zhang, D. Ultra-Supercritical Coal Power Plants: Materials, Technologies and Optimisation; Woodhead Publishing: Cambridge, UK, 2013.

6. Rheinhafen-Dampfkraftwerk Block 8 Achieved A 47.5\% Net Thermal Efficiency to World-Class Level. Available online: https: // www.world-energy.org/article/1198.html (accessed on 20 November 2020).

7. Tumanovskii, A.G.; Shvarts, A.L.; Somova, E.V.; Verbovetskii, E.K.; Avrutskii, G.D.; Ermakova, S.V.; Kalugin, R.N.; Lazarev, M.V. Review of the coal-fired, over-supercritical and ultra-supercritical steam power plants. Therm. Eng. 2017, 64, 83-96. [CrossRef]

8. Di Gianfrancesco, A. Materials for Ultra-Supercritical and Advanced Ulttra-Supercritical Power Plants; Woodhead Publishing: Duxford, UK, 2017.

9. Viswanathan, R.; Coleman, K.; Rao, U. Materials for ultra-supercritical coal-fired power plant boilers. Int. J. Press. Vessel. Pip. 2006, 83, 778-783. [CrossRef]

10. Rasheed, R.; Javed, H.; Rizwan, A.; Sharif, F.; Yasar, A.; Tabinda, A.B.; Ahmad, S.R.; Wang, Y.; Su, Y. Life cycle assessment of a cleaner supercritical coal-fired power plant. J. Clean. Prod. 2021, 279, 123869. [CrossRef]

11. Global Status of CCS 2020, Global CCS Institute, November 2020, Melbourne, Australia. Available online: https://www. globalccsinstitute.com/resources/global-status-report/ (accessed on 31 December 2020).

12. Mantripragada, H.C.; Zhai, H.; Rubin, E.S. Boundary Dam or Petra Nova-Which is a better model for CCS energy supply? Int. J. Greenh. Gas Control 2019, 82, 59-68. [CrossRef]

13. Rubin, E.S.; Davison, J.E.; Herzog, H.J. The cost of $\mathrm{CO}_{2}$ capture and storage. Int. J. Greenh. Gas Control 2015, 40, 378-400. [CrossRef]

14. IPCC Special Report on Carbon Dioxide Capture and Storage. Intergovernmental Panel on Climate Change; Metz, B., Davidson, O., de Coninck, H.C., Loos, M., Meyer, L.A., Eds.; Cambridge University Press: Cambridge, UK; New York, NY, USA, 2005; Available online: https://archive.ipcc.ch/report/srccs/ (accessed on 31 December 2020).

15. ZEP: The Costs of CO2 Capture, Transport and Storage, Post-demonstration CCS in the EU, European Technology Platform for Zero Emission Fossil Fuel Power Plants, Brussels, Belgium. 2009. Available online: https:/ /zeroemissionsplatform.eu/wpcontent/uploads/Overall-CO2-Costs-Report.pdf (accessed on 31 December 2020). 
16. Pale Blue Dot Energy. Global Storage Resource Classification Assessment: 2020. Available online: https:/ /www.globalccsinstitute. com/resources/publications-reports-research/global-storage-resource-assessment-2019-update/ (accessed on 31 December 2020).

17. Leung, D.Y.C.; Caramanna, G.; Maroto-Valer, M.M. An overview of current status of carbon dioxide capture and storage technologies. Renew. Sustain. Energy Rev. 2014, 39, 426-443. [CrossRef]

18. Lee, B.J.; Lee, J.I.; Yun, S.Y.; Hwang, B.G.; Lim, C.-S.; Park, Y.-K. Methodology to calculate the $\mathrm{CO}_{2}$ emission reduction at the coal-fired power plant: $\mathrm{CO}_{2}$ capture and utilization applying technology of mineral carbonation. Sustainability 2020, 12, 7402. [CrossRef]

19. Lee, B.J.; Lee, J.I.; Yun, S.Y.; Lim, C.-S.; Park, Y.-K. Economic evaluation of carbon capture and utilization applying the technology of mineral carbonation at coal-fired power plant. Sustainability 2020, 12, 6175. [CrossRef]

20. Nasirov, S.; O’Ryan, R.; Osorio, H. Decarbonization tradeoffs: A dynamic general equilibrium modeling analysis for the Chilean power sector. Sustainability 2020, 12, 8248. [CrossRef]

21. Kumar Shukla, A.; Ahmad, Z.; Sharma, M.; Dwivedi, G.; Nath Verma, T.; Jain, S.; Verma, P.; Zare, A. Advances of carbon capture and storage in coal-based power generating units in an Indian context. Energies 2020, 13, 4124. [CrossRef]

22. Yun, T.; Kim, Y.; Kim, J.-Y. Feasibility Study of the Post-2020 Commitment to the Power Generation Sector in South Korea. Sustainability 2017, 9, 307. [CrossRef]

23. Markewitz, P.; Zhao, L.; Ryssel, M.; Moumin, G.; Wang, Y.; Sattler, C.; Robinius, M.; Stolten, D. Carbon capture for $\mathrm{CO}_{2}$ emission reduction in the cement industry in Germany. Energies 2019, 12, 2432. [CrossRef]

24. Toktarova, A.; Karlsson, I.; Rootzén, J.; Göransson, L.; Odenberger, M.; Johnsson, F. Pathways for low-carbon transition of the steel industry-a Swedish case study. Energies 2020, 13, 3840. [CrossRef]

25. Adu, E.; Zhang, Y.; Liu, D.; Tontiwachwuthikul, P. Parametric process design and economic analysis of post-combustion $\mathrm{CO}_{2}$ capture and compression for coal- and natural gas-fired power plants. Energies 2020, 13, 2519. [CrossRef]

26. Vu, T.T.; Lim, Y.I.; Song, D.; Mun, T.-Y.; Moon, J.-H.; Sun, D.; Hwang, Y.-T.; Lee, J.-G.; Park, Y.C. Techno-economic analysis of ultra-supercritical power plants using air- and oxy-combustion circulating fluidized bed with and without CO2 capture. Energy 2020, 194, 116855. [CrossRef]

27. Liebenthal, U.; Linnenberg, S.; Oexmann, J.; Kather, A. Derivation of correlations to evaluate the impact of retrofitted postcombustion $\mathrm{CO}_{2}$ capture processes on steam power plant performance. Int. J. Greenh. Gas Control 2011, 5, 1232-1239. [CrossRef]

28. Stepczynska-Drygas, K.; Łukowicz, H.; Dykas, S. Calculation of an advanced ultra-supercritical power unit with $\mathrm{CO}_{2}$ capture installation. Energy Convers. Manag. 2013, 74, 201-208. [CrossRef]

29. Lucquiaud, M.; Gibbins, J. On the integration of $\mathrm{CO}_{2}$ capture with coal-fired power plants: A methodology to assess and optimize solvent-based post-combustion capture systems. Chem. Eng. Res. Des. 2011, 89, 1553-1571. [CrossRef]

30. Li, J.; Liang, X. $\mathrm{CO}_{2}$ capture modelling for pulverized coal-fired power plants: A case study of aan existing $1 \mathrm{GW}$ ultra-supercritical power plant in Shandong, China. Sep. Purif. Technol. 2012, 94, 138-145. [CrossRef]

31. Xu, C.; Li, X.; Liu, X.; Li, J. An integrated de-carbonization supercritical coal-fired power plant incorporating a supplementary steam turbine, process heat recovery and a modified boiler structure. Appl. Therm. Eng. 2020, 178, 115532. [CrossRef]

32. Jackson, S.; Brodal, E. Optimization of the energy consumption of a carbon capture and sequestration related carbon dioxide compression processes. Energies 2019, 12, 1603. [CrossRef]

33. Electric Power Research Institute. Engineering and Economic Evaluation of $1300^{\circ} \mathrm{F}$ Series Ultra-Supercritical Pulverized Coal Power Plants: Phase 1. EPRi Technical Update Report 1015699. 2008. Available online: https://www.epri.com/research/ products / 1015699 (accessed on 1 November 2020).

34. Tramošljika, B. Analysis of the Thermal Power Plant Plomin C: Comparison of Gas and Coal Variants. Graduate Thesis, Faculty of Engineering, University of Rijeka, Rijeka, Croatia, 2019. Available online: https:/ / urn.nsk.hr/urn:nbn:hr:190:542885 (accessed on 1 November 2020).

35. Lucquiaud, M. Steam Cycle Options for Capture-Ready Power Plants, Retrofit and Flexible Operation with Post-Combustion $\mathrm{CO}_{2}$ Capture. Ph.D. Thesis, Imperial College, London, UK, 2020. [CrossRef]

36. Espatolero, S.; Cortés, C.; Romeo, L.M. Efficiency improvement strategies for the feedwater heaters network designing in supercritical coal-fired power plants. Appl. Therm. Eng. 2014, 73, 447-458. [CrossRef]

37. Bejan, A. Power Generation, chapter 8. In Advanced Engineering Thermodynamics, 4th ed.; John Wiley \& Sons, Inc.: Hoboken, NJ, USA, 2016.

38. Feron, P.H.M. Absorption-Based Post-Combustion Capture of Carbon Dioxide; Woodhead Publishing: Duxford, UK, 2016.

39. Puxty, G.; Maeder, M. A simple chemical model to represent $\mathrm{CO}_{2}$-amine- $\mathrm{H}_{2} \mathrm{O}$ vapor-liquid-equilibria. Int. J. Greenh. Gas Control 2013, 17, 215-224. [CrossRef]

40. Kowalczyk, T.; Ziółkowski, P.; Badur, J. Exergy analysis of the Szewalski cycle with a waste heat recovery system. Arch. Thermodyn. 2015, 36, 25-48. [CrossRef]

41. Espatolero, S.; Cortés, C.; Romeo, L.M. Optimization of boiler cold-end and integration with the steam cycle in supercritical units. Appl. Energy 2010, 87, 1651-1660. [CrossRef]

42. Booras, G.; Powers, J.; Riley, C.; Hendrix, H. Engineering and Economic Analysis of an Advanced Ultra-Supercritical Pulverized Coal Power Plant with and without Post-Combustion Carbon Capture; EPRI: Palo Alto, CA, USA, 2015. Available online: https: //www.osti.gov/servlets/purl/1243059 (accessed on 1 November 2020). 
43. Hertwich, E.G.; Gibon, T.; Bouman, E.A.; Arvesen, A.; Suh, S.; Heath, G.A.; Bergesen, J.D.; Ramirez, A.; Vega, M.I.; Shi, L. Integrated life-cycle assessment of electricity-supply scenarios confirms global environmental benefit of low-carbon technologies. Proc. Natl. Acad. Sci. USA 2015, 112, 6277-6282. [CrossRef]

44. Pehl, M.; Arvesen, A.; Humpenöder, F.; Popp, A.; Hertwich, E.G.; Luderer, G. Understanding future emissions from low-carbon power systems by integration of life-cycle assessment and integrated energy modelling. Nat. Energy 2017, 2, 939-945. [CrossRef]

45. Khan, B.A.; Ullah, A.; Saleem, M.W.; Khan, A.N.; Faiq, M.; Haris, M. Energy Minimization in Piperazine Promoted MDEA-Based $\mathrm{CO}_{2}$ Capture Process. Sustainability 2020, 12, 8524. [CrossRef]

46. Jayaweera, I.; Jayaweera, P.; Elmore, R.; Bao, J.; Bhamidi, S. Update on mixed-salt technology development for $\mathrm{CO}_{2}$ capture from post-combustion power stations. Energy Procedia 2014, 63, 640-650. [CrossRef]

47. Kvamsdal, H.M.; Romano, M.C.; van der Ham, L.; Bonalumi, D.; van Os, P.; Goetheer, E. Energetic evaluation of a power plant integrated with piperazine-based $\mathrm{CO}_{2}$ capture process. Int. J. Greenh. Gas Control 2014, 28, 343-355. [CrossRef]

48. Li, H.; Le Moullec, Y.; Lu, J.; Chen, J.; Valle Marcos, J.C.; Chen, G. Solubility and energy analysis for $\mathrm{CO}_{2}$ absorption in piperazine derivatives and their mixtures. Int. J. Greenh. Gas Control 2014, 31, 25-32. [CrossRef]

49. Jilvero, H.; Normann, F.; Andersson, K.; Johnsson, F. Thermal Integration and Modelling of the Chilled Ammonia Process. Energy Procedia 2011, 4, 1713-1720. [CrossRef]

50. Darde, V.; Thomsen, K.; van Well, W.J.M.; Stenby, E.H. Chilled ammonia process for $\mathrm{CO}_{2}$ capture. Energy Procedia 2009, 1, 1035-1042. [CrossRef]

51. Moomaw, W.; Burgherr, P.; Heath, G.; Lenzen, M.; Nyboer, J.; Verbruggen, A. Annex II: Methodology. In IPCC: Special Report on Renewable Energy Sources and Climate Change Mitigation. 2011. Available online: https://www.ipcc.ch/site/assets/uploads/ 2018/03/ Annex-II-Methodology-1.pdf (accessed on 31 December 2020). 